\title{
PROBLEMS RELATING TO HYDROLOGY, WATER CONSERVATION, EROSION CONTROL, REFORESTATION AND AGRICULTURE IN CURAÇAO
}

\author{
QUESTIONS AND ANSWERS
}

TABLE OF CONTENTS

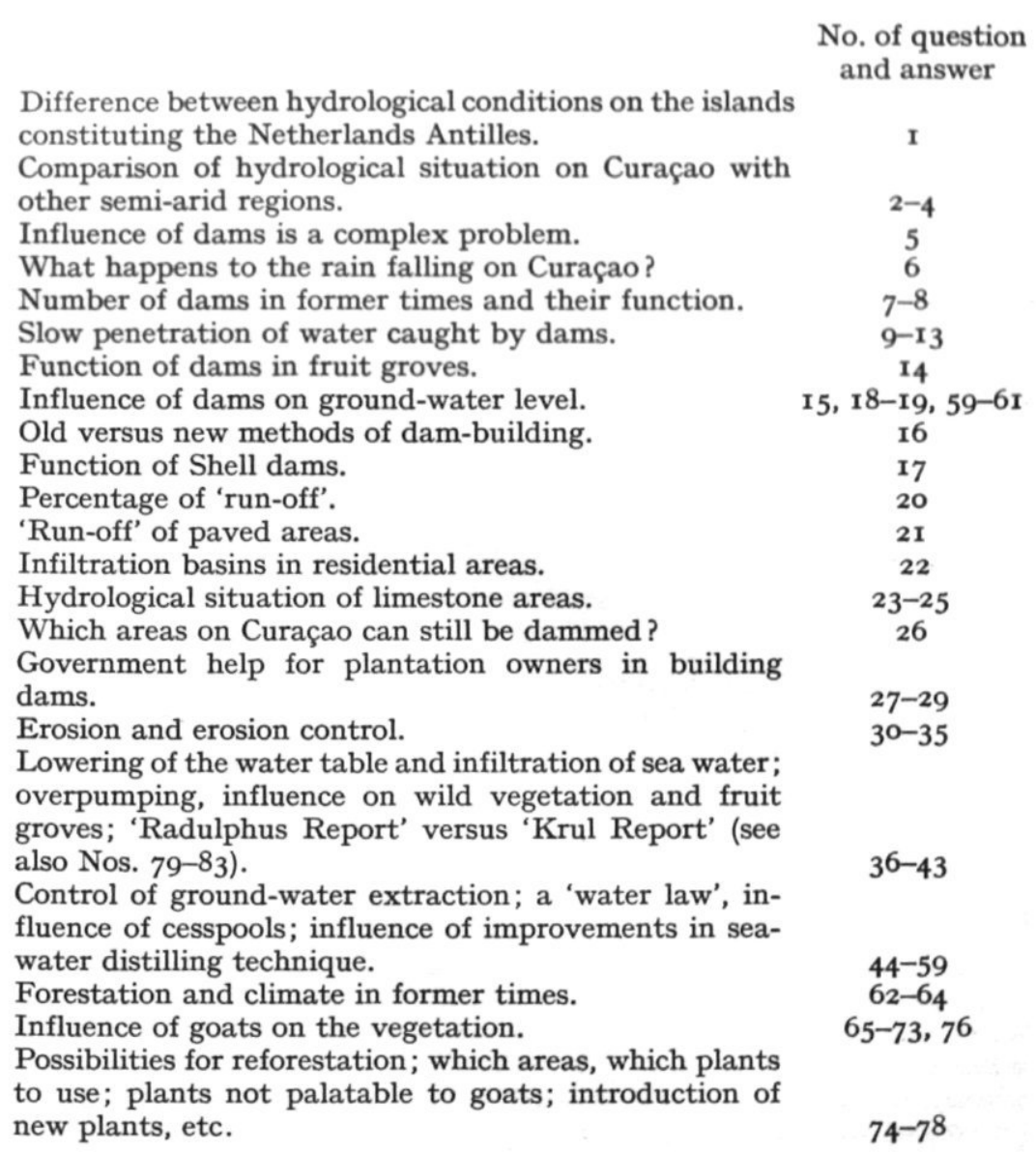

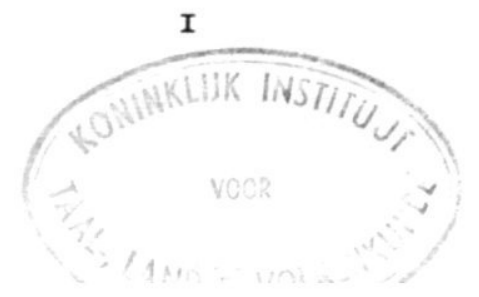


Reforestation, versus deforestation as advocated in the 'Krul Report'.

Deforestation still practised on Curaçao.

Geological data and hydrology.

Economic importance of agriculture in former times, and its decline.

Possibilities of re-establishing agricultural activities; evaluation for agriculture proper, horticulture, fructiculture, stock for meat production, dairy cattle, poultry, dry farming, rationalisation of horticulture and fructiculture.

Possibilities of cheap storage of water.

$79-83$

84

85

86

$87-104$

I03

105

REFERENCES

INDEX

Questions and Answers

Is the hydrological situation more or less the same for all the six islands of the Netherlands Antilles?

The hydrological situation differs considerably from island to island. It depends on $a$ ) total rainfall, $b$ ) pattern of rainfall, $c$ ) topographical pecularities, $d$ ) soil, $e$ ) subsoil, $f$ ) vegetation. - There is a large difference in rainfall between the islands of Curaçao, Aruba and Bonaire (Leeward Group) with a yearly average of about $500 \mathrm{~mm}$ ( $=20$ inches) and the islands of St.Martin, Saba and St. Eustatius (Windward Group) with a yearly average of about $\mathrm{I}, 000 \mathrm{~mm}(=40$ inches). Factors $c, d, e$ and $f$ are different for all the islands. Hence, few general statements are possible about the hydrological conditions on the islands, and any methods considered for use in improving the situation have to be studied for each island separately.

Is there any significant difference between the quantity of subsoil water (relative to size, of course) in Curaf̧o and in other well-known semi-arid regions such as Arizona, New Mexico, Florida and Israel?

There is a substantial disadvantage on the side of Curaçao.

3

How can this be explained?

One significant factor is the size of the island. Being surrounded by the sea, a small, hilly island is, of course, much more in danger of spilling its water (underground mostly) into the ocean or being infiltrated by sea water than large land masses. Large landlocked basins (as in Israel), in whose subsoil the water collects from extensive mountainous areas, are (of course) non-existent in Curaçao. - Another very important factor 
is the 'water-holding capacity' of the subsoil. There are two main types of subsoil out of which water can be extracted on Curaçao, viz: diabase and limestone. Let us consider the diabase first. Diabase is a magmatic rock. In unaltered condition it is a very hard and tough material with a blue colour. Its chemical resistance is, however, comparatively low, so that it is attacked by the salts and/or the carbon dioxide present in surface water. Hence, fissures appear, which spread slowly throughout the mass of the rock as the centuries pass. The diabase in its 'weathered' condition has a brown colour and is neither hard nor tough. - The water-holding capacity of the intricate network of mostly capillary fissures is, however low compared with the water-holding capacity of sedimentary material such as sand, clay and peat. This explains why the underground water situation of Curaçao is much worse than that of many other areas of like climatological condition. Only in the valleys, or in front of artificially built dams, is there enough sedimentary material and humus to guarantee a larger capacity for water storage.

4

How, then, is it possible that, in estimating the agricultural potentialities of the island, places like Arizona and Israel, where agriculture by irrigation is practised on a large scale, are so often pointed out as examples to which we should look?

The reason is that the profound topographical and geological differences and their implications are very often not clearly realized. - The erratic behaviour of the subsoil water in Curaçao is well known; 'good' wells occur very near 'poor' ones, 'salty' wells next door to 'sweet' ones. Everyone who has been engaged in digging wells on Curaçao will realize how bewilderingly complicated the subsoil structure is. Systematic knowledge of this subsoil is still completely lacking, and many observed facts are still unexplained. The diabase is often interspersed with impervious layers and pockets of 'caliche' (tightly packed fine-grained limestone) and clay (sometimes buried under layers of 'undisturbed' diabase). The weathered diabase itself has quite a different appearance and properties from place to place; there are layers and pockets of friable tuffs, etc.

5

Does not the building of dams help materially in conserving water in the subsoil?

The influence of dams on water conservation is a very complex problem. The real function and usefulness of dams can only be understood by a careful examination of the combined influences of the factors previously mentioned, viz: pattern of rainfall, condition of the soil, condition of the subsoil, vegetation and local topographical situation.

But, apart from any detailed evaluation of the influence of dams, is it not true that a large proportion of the rainfall is wasted as run-off into the sea. and every drop retained by dams is a positive gain? 
First of all, it is certainly not true in the particular case of Curaçao that a large proportion of the rainfall is lost by run-off into the sea. The pattern of rainfall is such that every six years there is usually one 'good' and (generally consecutively) one 'fairly good' rainy year. Only in these years is there any important amount of run-off (disregarding the paved areas such as roads, and areas with a large proportion of built-up surface, of which more will be said). In four (sometimes even five) out of the six years which compose every 'rain cycle' there is no run-off of any importance; but when it occurs (in a 'good' year) in a heavy and prolonged shower, the effect is very spectacular and dramatic. It 'sticks in the mind', creating a false impression about the percentage of rain water lost in the sea by surface run-off. - Much more water is lost in the 'dry' years with comparatively light showers of short duration. Only the 'upper crust' is drenched by these showers, and most of the water is quickly evaporated by the sun. Prolonged, not too heavy showers and/or showers following each other at fairly short intervals are best for 'deep penetration', thus benefiting the ground-water reserve.

The overall fate of the rain water, taken as an average for a six-years cycle, is as follows:

a) A relatively small percentage penetrates deeply enough to replenish the ground-water reserve. This occurs especially in the 'good' years of the rain cycle. The subsoil, however, is a 'leaky' reservoir, to be compared with a barrel pierced with holes at different heights. The higher the water level the more subsurface run-off there is into the sea. (In the dry years there is probably little subsurface run-off into the sea.) A second part of the stored water is taken up by deep-rooting plants, and the rest is extracted by wells.

b) Another much smaller percentage 'runs off' at the surface and is lost into the sea if not checked by dams. (Taken over one rain cycle, this percentage can be calculated to be $0.5 \%$ (at the most r \%) (see below).)

c) A large percentage penetrates only superficially and is subsequently lost by direct evaporation or taken up by plant roots.

$$
7
$$

Can these contentions be proved? And if so, what is the use of the dams?

To understand the function of the dams on our island let us first consider those which were built and used formerly, that is to say in the years before the economy of the island changed drastically owing to establishment of the oil company, and agriculture was abandoned by most people. - If we study the old topographical map of Curaçao we shall see a host of small dams, most of them $40-100 \mathrm{~m}$ long and perhaps $0.8-1.5 \mathrm{~m}$ high. More than a thousand dams can be counted in the region $16 \mathrm{~km}$ wide surrounding the city and the Schottegat (the area between a line from the eastern boundary of plantation Klein Piscadera to Hato mansion and a parallel line running from Fuik Bay to Seroe Mainshi, east of St. Joris Bay). - This was the situation at the beginning of the century. In the subsequent building splurge and the abandonment of agricultural activity, after establishment of the oil refineries and the tremendous increase of the population, nearly all these dams were removed in preparing building sites or have broken down through lack of maintenance. - The total number of dams which can be counted on the topographical map is 1,400 . 
8

What was the use of these small dams to the plantation owner or the small agriculturist?

The water caught in the dam basin infiltrated into the soil 'downstream' and the soil surrounding the basin, and kept it moist for a longer time than would have been the case if no dam had been present. The result of the dam was to prolong the planting and growing season. In the ground downstream and surrounding the dam basin sorghum, maize, several kinds of beans, ochro, peanuts, Curaçao cucumber (Cucumis anguria) and some other vegetables were grown. In the dam basin itself, water-melons, melons and squash were the usual crops, following the receding edge of the water (the pool disappeared slowly through penetration and evaporation). - It has to be emphasized that the dams could only function in the few 'good' years of the rain cycles (one or two every six years). The economic importance of this once-in-a-blue-moon agricultural activity in the former marginal economy of the island was still considerable.

9

In later years Shell Curaf̧ao N.V. (formerly: Curafaosche Petroleum Industrie Maatschappij, C.P.I.M.) and the Government have built high dams, the basins of which can hold large quantities of water. In some cases the penetration into the subsoil of the water caught by these dams is very poor. The water stays for a very long time, evaporating and leaking away in a small streamlet through the base of the dam. What is the reason for this slow penetration?

In several places the condition of the soil is such (denudation!) that a fine silt is carried along with the run-off water. This silt accumulates in the 'infiltration areas' of the dams, depositing a clayey layer which impedes or greatly hinders the penetration of the water.

There is yet another reason why the water stays above ground instead of penetrating. - As already said, the storage capacity of the diabase subsoil is not large. Whereas in the 'bad' years the percentage of rainfall 'penetrating deeply' to supplement the ground water is negligible, it may be relatively high in the few 'good' years. In these good years the subsoil becomes saturated (all the interstices being filled up). In particular, the subsoil below the dam basin and downstream in the neighbourhood gets saturated. This also hinders penetration. - Some spectacular dams of Curaçao, for example the large Muizenberg dam of the Shell Co. and several dams built by the Government in the second and third districts, show this phenomenon very clearly. - In certain valleys in the third district it can be seen that the subsoil in a good year is so saturated with water that wells overflow. Then the water flows slowly through the dams from one basin to the other till it is lost in the sea.

Io

What about ploughing up the infiltration areas before the rains start?

This might help in some cases, provided again that the subsoil is not too saturated. But ploughing will not be possible where the infiltration area is too uneven, rocky or stony or studded with trees. 
Would it not be possible to dig 'infiltration wells' in the dam basins, in order to circumvent the difficulties of penetration caused by the impervious silt layers mentioned?

Leading silt-laden run-off water into these wells will tend to clog the pores, defeating the purpose for which they were dug.

Then why not let the silt setlle first before admitting the water to the 'infiltration wells'?

The silt, if present, is very fine and settles very slowly. But even if it were to settle it would not help much when the subsoil has not enough extra 'storage capacity' for the mass of water which it should absorb.

Were these difficulties of penetration not encountered with the small dams of former times?

With the old small dams the difficulties were less. At each particular (low) dam there was a relatively small amount of water; a much larger percentage could penetrate without actually saturating all the surroundings and so impede further penetration. Secondly, the amount of silt deposited per unit of surface was smaller. Thirdly, this layer was mixed with organic material from the plants which were grown in the dam basin. - Note that the function of the small dams was to maintain moisture as long as possible in the 'root region' of the soil in as many places as possible which were particularly suited to agricultural activities. This purpose was quite different from the endeavour, by means of a few big dams, to force large quantities of water to penetrate deeply and join the ground-water reserve for storage there.

14

Now what was the function of the dams in the fruit groves ('hofjes') of the large plantations?

The plantations are situated mostly in broad valleys with a deep layer of sedimentary topsoil which is rich in humus. This makes the soil's capacity for water absorption large, much larger than in 'fissured diabase'. Moreover, owing to the innumerable roots in the hofjes and a thick cover of decaying leaves, the silt will not so readily form an impervious layer. - The function of the dams in fruit groves is not only to replenish the ground-water reserve. Firstly, the water in the ground is always more or less brackish. A fruit grove evaporates large quantities of water, the dissolved solids stay behind and a 'salting-up' of the soil would occur if it was not 'flushed out' from time to time by a good quantity of fresh water. - The dam also adds topsoil (as already stated, not as an impervious layer, since it is mixed with all kinds of organic matter from the grove). - It has also to be emphasized that the functioning of the dams in a plantation was always carefully watched and regulated. The spillway of the 
dam was closed by wooden planks, which could be taken out. Usually there were several dams in succession, one behind the other, and the water could be passed from one basin to the other by manipulating the sluices. If the soil became saturated and the water remained in the grove too long, the trees would be endangered (suffocation of the roots through lack of air). Draining-off the water was another function of the wooden sluices.

15

Some dams built by the Government Water Supply Service and Shell; and most of the dams built around 1950 by the Government Department of Agriculture, hold up all run-off before it reaches the lower-lying valleys where the fruit groves are usually located. - In the light of what has just been said, could this have any deleterious effect on these fruit groves?

It certainly could. It has been contended that the water which was checked upstream (if it penetrated and if it was not pumped out) would reach the groves by subsoil flow anyway, and thus bestow its beneficial influence in any case. This view, however, does not seem justified. Owing to the system of dams in front of and in the groves (or even without dams), the run-off reaching the groves would drench the subsoil through and through. The water table would rise to overflow the wells, and the accumulated salt would be flooded out. This thorough drenching of the soil and rise of the water table to above ground level will generally not occur with the slow and gradual subsoil seepage of water from the highersituated land. - This is one reason why the 'modern' system of dambuilding may have damaged the vegetation and may have contributed to the 'salting-up' of the valleys adjoining the sea.

I6

In the years around 1950 all Government-owned land on Curaço was provided with fairly large dams, methodically preventing all 'run-off'. Has this had an appreciable effect on the water level of wells in the areas during the dry periods?

To make a really reliable comparison it would have been necessary to collect numerous data from different wells before and after the building of the dams. This would have had to be done over a fairly long series of years, as the height of the water table changes between wide limits from year to year. In general it is not very probable that dams do have great influence on the water table in the dry years. They function in the good years, and the water which is added 'extra' through these dams is dissipated mostly through leakage underground and above ground, and used by the vegetation (wild or cultivated). - However, it can be assumed that the fairly large number (many dozens) of dams built by the Government in the second and third districts are of material help to the small agriculturists in that area, when they use their ground in 'good' years, in keeping the soil moist for a longer period. - In $195^{2} \mathrm{Mr}$. J. BEIJERING, who was in charge of the dam-building programme, started investigations to collect systematic data about the functioning of the dams, but unfortunately these investigations were discontinued. - It 
must be emphasized, however, that this relatively small number of big dams seems to have a much less beneficial influence on agriculture than the very large number of small dams $(1,400)$ which existed formerly. Moreover - as already pointed out - they may also endanger the fruit groves in the lower-lying valley by cutting off the necessary supply of run-off water ('flush effect').

17

If the old system of dam construction (many small dams) is the best one, why was this system not adopted around 1950 , when the Government undertook to provide all its land with dams?

The construction, but especially the maintenance of the many dams would have been much more difficult. The - relatively few - big dams which were built block the run-off practically completely. Most of them never overflow, and a concrete spillway is unnecessary. The small dams, however, in most cases need a specially constructed spillway. This spillway is the weak spot of the dam. Often the dam breaks at the boundary between earth and concrete; breaking of one dam also endangers the other dams downstream. - Moreover, it has to be borne in mind that the small dams were, so to speak, 'custom-built'. They took advantage of minute topographical and structural peculiarities of the terrain which were only known by those who had lived nearby for many years.

\section{I8}

The Shell Co. has built only twelve dams on its extensive ground holdings. How do they function?

The few big Shell dams are quite effective in checking all run-off. - Even if the penetration is bad the dams serve their purpose very well - a purpose which is, of course, quite different from that of what we may call 'agricultural' dams. Take the very illuminating example of the big Muizenberg dam. Let us say this dam has cost NA $f$ roo,ooo and is filled up only once in every six years, with 150,000 tons of water, which does not penetrate. Shell will withdraw this quantity of water in, let us say, six months, and in the meantime will import by tanker $\mathbf{1}_{50}, 000$ tons less water. The water brought in by tanker will cost more than $f_{\mathrm{I}}$ per ton. The dam therefore means a saving of at least $f \mathrm{I}_{5} \mathrm{O}, 000$ every six years. Hence the building cost proves to be a good investment.

19

Is it possible to give a rough quantitative estimate of the influence of dams on replenishment of the ground-water reserve?

This influence can be very roughly estimated in the case of the Shell dams. The total holding capacity of those dams is about 500,000 tons. We may assume that once in a six-years cycle they catch 500,000 tons, and once 250,000 tons, total 750,000 tons. Of these, 400,000 tons may infiltrate. Now compare this with the quantity extracted by Shell in six years. This is roughly $5,000,000$ tons. To this 5 million tons must be added the quantity which is lost in the sea by subsurface run-off, and the quantity taken up by 
plant roots. These quantities ( $x$ and $y$ ) are certainly important, but they are unknown. If at the end of each six-years rain cycle the situation is exactly as it was six years before, the quantity of water infiltrated must be equal to the quantity which was used up in one way or another, i.e.: total infiltration $\left(I_{t}\right)=5$ million $+x+y$. Now the total infiltration is equal to the infiltration outside the dam basins $\left(\mathrm{I}_{\mathrm{o}}\right)$ plus the infiltration inside the dam basins $\left(I_{d}\right)$, therefore: $I_{0}+I_{d}=5$ million $+x+y$. - As $I_{d}$ is 400,000 tons, it follows that $I_{d}$ is only a small fraction (much less than $10 \%$, probably only a few percent) of $I_{0}$. This means that nearly all the water infiltrating into the soil to join the ground water does so outside the dam basins. Hence the influence of dams on the total ground-water reserve is small. - This is an indication that, contrary to general belief, the function of dams formerly was not to ensure a general rise of the ground-water table but primarily to help agriculture in the way already discussed.

May it then be contended that the influence of dams on the water level of wells situated downstream from the dam is not great?

Such a statement is not permissible. Temporarily the influence may even be very great. Even if the dams add only a few percent to the infiltration in the entire catchment, a relatively large quantity of water is collected by the dam in a very restricted area. Hence, in places the water level downstream from the dam may be raised considerably. However, the many specific conditions of the locality determine how long this influence will last, that is, how fast or how slowly the locally collected water will dissipate, through subsoil flow and use by vegetation.

2 I

Is it possible to give an estimate of the run-off expressed as a percentage of the total rainfall?

Yes, this is possible. In the foregoing it was estimated that about 750,000 tons of water were caught by the Shell dams in every six-years cycle. Shell extracts an average of about 5 million tons in six years. The company's policy is to limit the extraction to $3 \%$ of the total rainfall. The total rainfall on Shell's combined catchments is therefore about 165 million tons. Since virtually all run-off on the Shell catchments is held back by the dams, the total run-off taken as a percentage of the total rainfall in a six-years cycle is only about $0.5 \%$ (not taking the paved areas into account, of course). - This value is very much lower than is suggested by popular belief. But even if there might be some difference of opinion about the quantity of water held back by the dams, by no stretch of imagination would it be possible for that to exceed $\mathrm{I} \%$.

22

In the foregoing, it was stated that the case of 'paved and built-up areas' would be treated separately. What is the difference between these and other areas?

The big difference is that in the 'paved and built-up areas' there is much more run-off much more frequently. Even a light shower will not penetrate 
a paved road. Accordingly, even in 'dry' years there would be run-off, while the subsoil is not saturated. This run-off would be quite useful if forced to penetrate. The tragedy is, however, that it is just in these residential districts that there is no room for dams, with their 'infiltration areas'.

Should we not plan the development of Willemstad in such a way that, with future expansion, adequate room is left in which to build dams, and lead the run-off from the roads and roots to these infiltration areas?

From the standpoint of mere water conservation this should certainly be encouraged. There are, however, several considerations which make a solution extremely difficult. Let us take a practical example. The residential area called Damacor seems very well suited to water conservation: a broad valley with a relatively deep layer of topsoil rich in humus of high absorptive capacity. From the standpoint of water conservation the houses should have been built in the hills around the valley, whilst the valley itself should have been used as infiltration area, with dams all over it to catch all run-off from the surrounding roads, etc. It is, however, easy to see that houses in the hills have a number of disadvantages compared with houses in the valley. Some houses (at the top of the hills and on the eastern slopes) will be too windy, some others (at the western, lee side) not cool enough. Site preparation and building will be more expensive. Layout of roads is more difficult, and building them more expensive. Moreover, it would be very difficult to keep gardens, since good topsoil and well water are both lacking in the hills!

To ensure water conservation in residential areas, a very strict zoning law would have to be adopted. This, however, would deprive landowners and prospective house-builders of the best and most valuable building sites! It is very doubtful whether such a law would ever be passed and enforced. - A zoning law to regulate the development of the city, the valleys and the outlying districts is very necessary, not only from the standpoint of water conservation, but also from every other standpoint which has to do with proper city planning, if we want to avoid or curb the chaos which is now threatening to engulf us. From 1945 on the Department of Public Works has been urging this kind of law, but nothing has been achieved so far. We have to take into consideration the fact that the old 'liberal' principle of tinkering as little as possible with private property is still powerful here. In many European countries this principle has been abandoned (especially in Holland, where there is exemplary town and landscape planning), but even in the United States, notwithstanding the growing influence of planners and conservationists, it is still causing much irreparable damage. - Nevertheless, it might be possible to do something. Mr. Beijering of the Department of Public Works, who was in charge of the Government dam building programme around 1950, has proposed that the run-off of the roads should be led off along the side walks into numerous small infiltration basins alongside the road. A careful planning of new housing development would be necessary to ensure this. At least a fraction of the run-off might be saved in this way, and trees might be planted in the infiltration basins. 
24

In the foregoing, the situation in the diabase areas has been discussed. What about the limestone areas?

The limestone plateaux we have are porous and an excellent agent for holding water. A yearly average of about 40 million tons of water falls on the plateaux, and if a considerable amount penetrates and is stored it may be a very valuable contribution to our ground-water reserves. They could probably be tapped without much damage to the vegetation. - The only permanent springs which we have on Curaçao (at Hato and San Pedro) originate in the northern limestone plateau. The very existence of the springs, however, indicates that the limestone - at least in some places - meets more or less impervious underlying layers dipping towards the sea, so that the water runs off (mostly underground, probably) to the sea. There are some indications that in other places the impervious layer may dip in an opposite direction, thus leading the water 'inland'. Just as previously stated regarding the diabase areas, the subsoil structure of the limestone plateaux is of a bewildering complexity. - In a few places where there is enough topsoil for cultivation on the plateaux wells have been drilled, giving a relatively abundant water supply (plantation Noordkant and north of Ronde Klip; in both places there is a dairy farm with irrigated 'green food'). - It would perhaps be worth while investigating the underground water situation of the limestone plateaux by systematic drilling and/or with the help of modern physical methods, which would enable, for instance, continuous subsurface profiles to be constructed. This, however, would only be of practical value if there is enough topsoil for agricultural purposes at the location (which generally is not the case) or in the near vicinity (e.g. diabase valleys to the south of the northern limestone plateau).

\section{5}

If the limestone plateaux may be good sources of water why were they not tapped in former times by plantations bordering them?

Formerly there was no mechanical drilling equipment on the island, and hand-digging of wells in the hard limestone is virtually impossible.

26

If the limestone plateaux have a good water-retaining capacity, would it not be worth while to build dams exactly in these areas?

Unfortunately the topographical situation in most cases does not seem to facilitate the building of dams. Moreover, infiltration seems to be so good in many places that there is very little run-off. This question might, however, be worth studying more closely.

27

Are there still extensive areas on the island which could be dammed?

On the map we can see that nearly all Shell and Government-owned land (except the residential areas) has been provided with a system of dams 
which prevents a very great part of the run-off from being wasted in the sea. But there are still large tracts of privately owned land where the system of dams could probably be improved. The total area concerned is, however, less than that of the Shell and Government ground.

28

Should the Government step in and offer to help the estate owners to provide their ground with a system of dams or to improve the system of dams which they already have?

It has to be borne in mind that most of the estate owners would not be willing or be in a position to contribute financially to the implementation of such a scheme. Most probably they would not object to it, provided the dams were built on places approved by them.

\section{9}

Should there be a law permitting the Government to build the dams at the spots on the estates where the Government experts want them to be situated?

Such a law would not be without danger. In many cases the experts of the Government would not be justified in trying to impose their views on the plantation owner. - As long as so little (virtually nothing) is known of the structure of the subsoil, judgement about the location of dams, etc., is to a considerable extent empirical, and the estate owner, who 'knows his ground' is in a much better position to judge than others. - Moreover, as is clear from the foregoing, the dams have to fit a certain agricultural pattern. Hence, we have to decide first what we will do with the soil (horticulture, fructiculture, staple-food production or production of green food) and where we are going to do it, before we decide how and where to build the dams.

30

So there might be controversies between the estate owners and the Government experts?

This would certainly be the case. One example may be mentioned. The broadest valleys with the greatest extent of flat land and the deepest layer of topsoil are generally situated near the sea. There the fruit groves used to be located, and agricultural activities were most pronounced. Damming of the 'upstream' parts of the catchment would deprive the lower-lying lands of much surface water which is deemed essential for the growing of fruit and for the other agricultural activities (this has already been explained). But damming of the upstream parts of the catchments was exactly what the Government did in the third district around 1950, in the expectation that the water caught upstream would somehow benefit the lower-lying valley ground. - In the foregoing, however, the reasons why this view cannot be accepted have already been discussed.

3I

How is the situation with regard to erosion?

Soil erosion is indeed serious in several places. As the hills have been denuded for the purpose of cultivation and charcoal burning, a great deal of 
soil is washed away every time there is considerable run-off. As pointed out, this run-off water contains much silt. In the hills which are still well provided with forests, such as those in Zevenbergen and Wacao, the runoff water is much clearer.

\section{2}

What happens to the silt carried away with the run-off?

Formerly the silt which was washed away was deposited in the basins of the innumerable little dams strewn all over the country. Nowadays it collects in the basins of the big dams built by Shell and the Government. In places where the former dams have been destroyed and no others have been built (e.g. in the residential areas around the Schottegat) the silt is lost in the sea.

33

Is anything in particular being done to check erosion? Is contour ploughing practised?

In the little patches in the hills which are still cultivated, ploughing is actually often done in the right way. However, most of the deforested hills are not cultivated any more. Especially to the east of the Schottegat, many have not recovered a secondary vegetation, and with others this secondary vegetation is so poor that it offers scant protection against erosion. - Formerly, some fruit groves in other places seem to have had a series of low stone banks, perhaps only about $20 \mathrm{~cm}$ high, one after the other, to prevent the topsoil from being washed away. It is said that the banks were of diorite, and, this being a hard and valuable stone and scarce on the island, they were sold for building purposes after the decline of plantation activities. These low stone banks were called 'fahas'.

\section{4}

Were these 'fahas' not built in the hills?

As far as is known, they were built in only a few places in Curaçao. In Aruba, however, they can still be seen at various places, and they really serve their purpose very well.

35

Should not these 'fahas' on the hillsides be tried out again in Curafao?

It would be very worth while. In Aruba, however, they are much easier to construct, as most hillsides are themselves strewn with (diorite) blocks, so that the building material is ready to hand. In Curaçao this is not the case.

$$
36
$$

It has been proposed to 'ring' the diabase hills, which means to dig shallow trenches every ten to twenty meters along the contour lines and throw up a little dam with the soil removed from the trench. Could this provide a satisfactory solution? 
The method was tried out on a small scale at Klein Kwartier in $195^{\circ}$ on a not very steep hill. At the moment, its influence is clearly to be seen. All the trenches and dams are overgrown with dense shrubbery of Mimosa distachya (uña di gatu), a shrub up to $2 \mathrm{~m}$ high with very sharp, clawlike thorns. - It is, however, doubtful whether this method is applicable to steeper hills. But the greatest practical difficulty is that the very hills which need erosion protection most are private property near the residential areas, and may be used for housing projects at any moment.

37

Are there any serious signs of lowering of the water table by the extraction of ground water through wells?

There are certainly many alarming signs.

38

Are there reliable data indicating just how far the lowering of the groundwater table has proceeded in the afflicted areas?

Unfortunately there are no reliable data. Many systematic observations in various places and throughout many years would have been necessary before and after the start of water extraction. Even now, in 'good years', wells may overflow, but in the subsequent dry years prolonged extraction does dangerously affect the water level.

39

Is the dying of trees in former fruit groves ('hofjes') always a sure sign of overpumping? - Shell assures us it keeps track of the salt content of all its wells, and that very carefully!

Dying of trees in former groves is not necessarily a sign of overpumping. Some fruit groves (situated on higher ground) have always needed irrigation, at least in drought periods. When the plantations were abandoned the trees died, since irrigation stopped. Neglect of the dams (the influence of which has already been discussed) may also have hastened their decay. - Sure signs of overpumping are, however: death of the trees in groves which have not been neglected and which did not need artificial irrigation; death of 'natural' wild vegetation; and, most objective of all, salting-up of the wells through the penetration by sea water.

Keeping track of the salt contents of wells, when used as an argument, is quite beside the point. If the wells which Shell uses for its groundwater extraction, and which are all situated at a distance of several kilometers from the sea, begin to 'salt up', much harm has already been done in the groves nearer to the sea. Any 'watch' for sea-water penetration through overpumping should be kept near the sea. When the Shell wells react it is already much too late!

40

Where can these signs of overpumping be observed? - Is it not claimed that exactly in the plantations owned by Shell the situation of the fruit groves is satisfactory? In this connection Groot St. Joris and Groot Piscadera are mentioned. 
These signs can be observed, for instance, in the residential areas at the east side of the Schottegat (Groot and Klein Davelaar, Zeelandia, Suikertuintje, Pos Cabaai, Rooi Catootje, part of Mahaai), St. Barbara, Brakke Put, Zuurzak, and at the west side of the Schottegat (Klein Piscadera, Groot Piscadera, Blauw and Rafael).

Again, there are some pathetic and very recent examples proving that the dying of fruit groves cannot be attributed only to neglect. The owners of Rooi Catootje and Blauw and the tenant of Groot Piscadera are fighting a losing battle against the decline of their fruit groves, notwithstanding their frantic and ceaseless efforts to save them. The fruit grove of Blauw died well-nigh completely in the drought-stricken year 196r, since no water was available for irrigation, notwithstanding deepening of the wells to far below former depths. The water table in the splendid 'big' fruit groves of Groot Piscadera (situated so low that it never needed irrigation) has fallen so much that many trees (even some of the very hardy tamarind trees) have perished. The 'little' fruit grove of the same plantation, replanted in $195^{\circ}$ with excellent varieties of mango trees, citrus and dwarf coconut, and thriving splendidly at one time as a result of the unremitting efforts of the tenant, is now in a sorry state, with the exception of the coconut trees. This 'small' grove (3-4 ha), situated on somewhat higher ground than the 'big' one, had always to be irrigated during the dry seasons with 80 tons of well water daily. This quantity could no longer be extracted in $196 \mathrm{I}$, and the salt content of its two wells jumped from 250 and $400 \mathrm{ppm}$ chlorine to 4,000 and $5,000 \mathrm{ppm}$ respectively! - Here we have two striking instances where there is no question of neglect or adverse influence by roads and residential areas in the neighbourhood!

Shell's claim is not true, unfortunately. In Groot St. Joris more than 5,000 coconut and many mango trees died in the late twenties after Shell started pumping in that area. Sea-water penetration seems to have occurred in those parts of the grove nearest to the sea. Again, in the last drought period many sapodilla (mispel) trees succumbed, even when they were much farther away from the shore. - In Groot Piscadera the large low-lying fruit grove is in a state of extreme suffering, to such an extent in fact that even the very hardy tamarind trees are languishing away. The wells in the well-kept 'upper' fruit grove turned brackish in 1961.

$4 \mathrm{I}$

Formerly it has always been emphatically denied by the Government Water Supply Service and by Shell that the death of fruit groves and other vegetation was due to ground-water extraction. What is their standpoint at the present time, and what value can be assigned to their arguments?

The Government Water Supply Service now readily admits the influence of its water-extraction operations. The standpoint of Shell Curaçao N.V., however, is different. The company claims that only a maximum of $20 \%$ of the water percolating into the soil is extracted, and that if this were not pumped off it would in any event be lost by running underground into the sea. Furthermore, it is said that the water table would inevitably drop towards the end of the dry period, irrespective of whether water was pumped out of the soil or not. - The estimate that only $20 \%$ of the water which penetrates to replenish the ground-water reserve is 
extracted may be right (by chance, for sufficient data to back such an estimate are lacking), but this is beside the point. The same applies to the - obviously very true - argument that "the water table would inevitably drop towards the end of the dry period".

The situation is as follows. After the 'good years' of the rain cycle the water table steadily drops. At a certain moment it will be as low or nearly as low as the sea level, in the valleys adjoining the sea. This means that the (heavy) vegetation in these valleys (fruit groves!) will evaporate as much water as it receives by subsoil seepage from the higher ground. The 'certain moment' will be reached the earlier the more water is extracted by wells in the catchment. When this is so, a dangerous situation arises: the vegetation may evaporate more water than it receives underground from 'higher up'. In that case the water table drops below sea level, and sea water penetrates. It is exactly this that has happened all around the Schottegat ! - Very generally it can be said: drought periods are critical periods for the vegetation. The situation is 'marginal', and even moderate lowering of the water table, or extension of the 'most dangerous period' in each rain cycle for a few months, may mean death for splendid and luxuriant fruit groves. - The fact remains that the quantity of water which is extracted daily from the subsoil in critical drought periods by Shell and the Government would be enough to help many dozens of lush fruit groves, each the size of Zuikertuintje, through this critical period!

In other words: the argument that only $20 \%$ of the water infiltrated to join the underground reserve is extracted, if this figure is calculated as an average for a complete rain cycle, does not mean much. In the critical period at the end of a rain cycle the extraction may become a dangerous competitor of the vegetation, perhaps using up a considerable part (much more than $20 \%$ ) of the water which would have been available for the use and survival of the latter.

42

This may be true, but Shell spent much effort on water conservation measures like dam building. May the infiltration not have been materially improved by these measures?

In the foregoing it has already been calculated that the 'extra' quantity of water penetrating into the soil through the Shell dams is not more than about $10 \%$ of the quantity extracted by Shell.

\section{3}

So what about the claim that water management by Shell has been excellent, and that no 'overpumping' has occurred?

Let us assume that the Shell data indicate that the water levels in the control wells return to their previous heights after each rain cycle. From the standpoint of the man who extracts water and who wants to go on extracting the same quantity every rain cycle this is, of course, a good indication that no 'overpumping' is taking place (though it could be intimated that in many places the relation between storage capacity and deeply penetrating water is such that the water levels in the wells would more or less return to their previous heights after the 'good' years, even if 
in the 'bad' years every drop had been extracted from the subsoil). As already pointed out, however, this by no means implies that no damage is done to the vegetation, or that no sea water will penetrate in the valleys adjoining the sea. The - glaring - facts indicating to the contrary cannot be 'talked away' (see, for example, the situation at Klein Piscadera, Groot Piscadera, Blauw and Raphael, already discussed).

\section{4}

Looking back after a period of 15 years, what can be said about the dire predictions and warnings of the 'Radulphus Report'? (In 1945 the Governor of the Netherlands Antilles appointed a Committee to investigate the complaints about the alleged harm done by ground-water extraction to agriculture, horticulture and scenic beauty. This committee was known as the 'Commissie Radulphus' (Radulphus Committee).)

Although, of course, not every one of the contentions in that report can be accepted as scientifically sound, it can be said that in general its forebodings were justified by subsequent events. It is only fair to acknowledge this and pay belated tribute to the authors - laymen - whose views were repudiated and made to appear more or less ridiculous by the 1949 ' $\mathrm{Krul}$ Report', prepared by experts. (Of this latter report more will be said presently.)

In fact, we have had in Curaçao a repeat performance of what has happened in Holland. In that country there has been a decades-long controversy between nature lovers and conservationists on the one side and experts of the Water Supply Service on the other side, the first claiming that water extraction from the dunes had caused much harm to vegetation, the last denying this and branding the contentions of the first as 'old wives' tales'. Eventually the ground-water situation became so critical that water from the River Rhine had to be pumped into the dunes. Soon after, the water table was rising and vegetation and wild life were re-establishing themselves splendidly!

\section{5}

Could we be optimistic about the results of stopping the water extraction by the Government and Shell?

It is to be feared that much optimism - at least at short-term - is not warranted. It seems difficult to 'push back' the sea water which has penetrated, not to speak of restoring the fruit groves which fringed the south coast of the 'second district'. - This, of course, does not mean that it is unnecessary to stop the extraction. If this is not done the situation will get worse and worse.

\section{6}

How much water is being extracted from the subsoil in the area around the Schottegat, and by whom?

Shell extracts from about $\mathrm{I}, \mathrm{IOO}$ tons/day (in the dryest years) to about 3,500 tons/day (in the best years); the Government Water Supply Service has diminished its extraction to a few hundred tons/day. (Formerly, up 
to 1,000 or 1,500 tons/day was pumped.) On an average, $3,000-3,500$ tons of water used to be withdrawn daily from the second district by Shell and Government. Moreover, there are a great many wells attached to private homes. How many we do not know, but it may well be a few thousand. Much less is it possible to guess the total quantity of water extracted from these wells. It varies in most cases from a few hundred liters to a few tons per day.

47

\section{Is there anything to be done to stop or limit this water extraction?}

The Government Water Supply will stop as soon as the new water-distilling plants, that have now been ordered, are installed, which will be presumably within a year or so. After installation of these plants Shell will buy large quantities of water from the Government, and it may be possible to persuade this Company to stop the extraction altogether (at least in very dry years) or to reduce it considerably.

\section{$4^{8}$}

But what about the other private well owners? Is it possible to control their pumping too?

The promulgation of a 'water law' has been advocated, according to which all subsoil water would be declared Government property. Every well owner would be compelled to attach a water meter to his pump. A government agency would be organized to record periodically the readings of these water meters. Moreover, the water level and salinity of each well would also be recorded periodically. Out of all the information gathered in this way criteria would have to be established stipulating how much water each well owner would be allowed to use.

\section{Would this be a practical solution?}

It is to be feared that an endeavour to ensure 'water management' in this way is fraught with difficulties. There is such a great difference from year to year and from place to place that at least two 'rain cycles" would be necessary in order to obtain any notion of the 'subsoil hydrological cycles', even with the most careful observation and elaborate organisation. To distil any criterion out of these observations would be a hazardous enterprise.

Would there be an allotment 'per well' or per unit of land owned? What if a man has a nice fruit grove around his house, or a well-kept garden? Should he let it die in dry years, when the Government orders him to limit his pumping? - To give another practical example: most wells in Damacor have enough water even in the worst years. The houses in that area have nice gardens. Must we restrict pumping in Damacor, thus endangering the vegetation in that area, in order to save the vegetation in some parts of Mahaai, where wells are salting up, even if we were certain that the extraction in Damacor affects Mahaai? Then take this example. A gentleman in Mahaai has quite a number of fruit trees 
around his house. His garden is part of the grove of a former large plantation. If the trees evaporate let us say $\mathrm{x} \mathrm{m}^{3}$ water per day, and he was to irrigate with $\mathrm{x} \mathrm{m}^{3}$ water, the salt concentration of the moisture in the root region of his garden would increase tremendously and the trees would die. To hold down this salinity he has to use much more water than $\mathbf{x} \mathbf{m}^{3}$ per day. This water, however, is not used up, but is largely recirculated. Can we prohibit the man with the nice garden from irrigating with the quantity of water he needs, and thus condemn the remnants of the former splendid grove to a certain death? Would we not defeat our own purpose by such actions? And these are only a few of the problems which would arise if we were to try to control all privately owned wells. It would surely lead to a hopeless tangle of bureaucratic red tape, disputes and controversies.

If water management in this way is virtually impossible to put into practice, must we then resign ourselves to a situation which will get worse from year to year?

Certainly we must not, nor do we need to. First of all, as already said, the Government Water Supply and Shell have to stop their pumping. Then we have to strive for very large distilling plants turning out water at very much lower cost than at present. New developments in distilling technique point to the possibility of providing the public with water at say about $40 \mathrm{ct}$ per ton ( $=80 \&$ per 1,000 gallons). (The price is now five times as high!) With this price, very many people will eventually stop extracting water from the subsoil: wells and pumps need maintenance, good technical service is very difficult to get. Any repair on a windmill or electric pump is usually a headache, and an expensive headache at that. But if the people do not stop of themselves, the Government - delivering such low-priced water - will be perfectly justified in prohibiting water extraction, possibly making exceptions for vegetable gardens, fruit groves, etc.

$5 \mathrm{I}$

So we may be saved by improvements in sea-water distilling technique?

That is correct. In this connection, another very important factor has to be mentioned which is as often as not - no, always - overlooked. This is that the private well owners in the residential areas not only extract water from the subsoil but also replenish the ground-water reserve. The situation is generally such that the owners of wells use well water for their gardens and tap water (which is at the moment almost purely distilled water and in the near future will be $100 \%$ distilled water) for household purposes. The houses which do not have wells use tap water both for household purposes and for their gardens, but usually cannot afford a garden of any size, in view of the present price of tap water (NA $f 2$ per $\mathrm{m}^{3}$ or about 4 per $\mathrm{I}, 000$ gallons). Now the water used for household purposes in the residential areas is drained into cesspools and thus infiltrates nearly 100\% into the soil, replenishing the ground-water reserve (only part of the city proper has a sewage system leading the water into the sea as waste). 
It can be estimated that in the residential areas a few thousand tons of water per day are already being added to the ground-water reserve, and that in the future much more water will be added to the soil than extracted from it by the citizens. The total quantity of water delivered by the Government Water Supply Service to the citizens is at the moment about 6,500 tons/day. At the Punda side there is a sewage system up to Julianaplein, at the Otrabanda side up to Plantersrust. The director of the Government Water Supply system estimates that those parts of the city consume about 2,000 tons of water per day. Hence, about 4,500 tons per day is supplied to houses with cesspools. If, of this 4,500 tons, one third is 'lost' (mainly water used for gardens; this is a liberal allowance), 3,000 tons are daily returned to the ground water, all in the areas around the Schottegat. - This has a very important implication, namely that prohibition of extraction by the small consumers is morally not very justified unless the Government can provide cheap water.

So regulation of ground-water extraction by the 'small consumers' will be impractical and of doubtful necessity and moral justification?

I think this is quite correct! Most small consumers not only extract water from the subsoil but also add water to it.

Incidentally, this fact may provide us with a certain criterion of what we want in order to make a 'water law'. Such a law might, for example, contain the following provisions:

a) A general ban on the use of well water except in the following cases:

i) For household purposes when the house is also connected to a water supply system using water which was not extracted from the subsoil. ii) For household purposes when the house is situated in a place where it cannot be served by the water supply system.

iii) For agricultural purposes.

iv) For industrial purposes (e.g. laundries) after grant of a permit, when the used water is returned to the subsoil or used for agricultural purposes.

b) The Government should be entitled to control the depth of all wells.

Now what about the ground water extracted by Shell? Does it return to the soil in any manner?

The houses of the Shell colony do not have cesspools. The water is collected in a sewage system and discharged into the sea.

\section{4}

But at the new Government low-cost housing estate at Brievengat an elaborate sewage system has been constructed, with pumping stations to take the water to the sea on the northern coast of the island. Why was that done?

Presumably considerations of maintenance of cesspools and hazards to health have played a role. 
55

Would cesspools have cost more than the sewage system?

No, this is not the case; cesspools, if well constructed, require little maintenance; the pump of the sewage system also requires upkeep.

56

But is it not true that cesspools will only function well for a limited number of years? That the walls through which the water has to penetrate will apparently clog, so that a new pool has to be dug?

This is the case if the water of kitchens and laundries is allowed to drain into the cesspool. The fat in kitchen water is not easily decomposed by bacterial activity, whilst the detergents in kitchen and laundry water may kill a lot of the bacteria. For this reason kitchen and laundry water have to be disposed of separately in a septic tank with two compartments. The sludge deposited in the tank has to be cleaned out every year or two, which is quite easily done.

\section{7}

But expert advice was apparently solicited before the decision to construct a sewage system was taken?

That is so. The question was asked whether it would be economically feasible to collect the sewage, purify it in a sewage treatment plant, and use the water thus treated for any good purpose. The answer of the experts to that question was - quite rightly - no.

\section{$5^{8}$}

What are the advantages of a cesspool?

The cesspool is a good device for replenishing the ground water (and for adding nutrients to the soil). Silt-free water of very low salinity is introduced into the ground in small portions in many places; moreover, this water is not exposed to sun and air.

59

But could not cesspools be dangerous to health?

When a well is dug too near to a cesspool, and the water of the well is used for an unsuitable purpose (e.g., for drinking or washing dishes without boiling), there is certainly a possibility of infection; but at Brievengat none of the houses was provided with a well.

It has to be borne in mind that water passing through the soil is subjected to biological purification. - Wells and cesspools in the same garden have always been standard practice in the residential areas around Willemstad. Care is taken to construct them as far apart as possible. I do not think they present any problem, as everyone is well aware that unboiled well water should only be used to irrigate the garden and to flush the toilets. 
How does the quantity of water infiltrating through the cesspools compare with the quantity of water saved by the dams?

It has already been stated above that about 400,000 tons of water are forced into the ground by all the Shell dams during every rain cycle. This compares with about $6,500,000$ tons infiltrating through cesspools, - Moreover, the dam-saved water we get in one big gulp, at a few places, whilst the cesspool-saved water is evenly distributed from day to day and from place to place.

$6 I$

But perhaps more water could be saved by dams in the areas around the Schottegat?

This would not be so, since Shell has taken very great pains to catch as much of the run-off as possible on the vast tracts of land which it possesses. The same applies to the Government. An explanation has already been given as to why it is virtually impossible to build dams in existing or prospective residential areas.

62

It seems, then, that the influence of the dams in the total picture of water conservation is very small, and the question might be asked whether dambuilding has any sense at all?

The influence of dams in the total picture of the subsoil water situation is indeed small, but that certainly does not mean that the building of dams is of no value. Dams do have a localized influence, and are of great importance precisely at those spots where a 'gulp' of fresh water once in a while has a beneficial effect. This is at those places where 'plantation activities' are going on, as extensively explained above. - Moreover as already said - dams are useful for catching the topsoil washed away from the many denuded hills.

Climate, vegetation and hydrology are considered to be interrelated. There is a fairly widespread belief among laymen that there was much more vegetation on Curacao at the time when the island was first colonized by the Dutch, more than three hundred years ago, and that on account of this heavier forestation there was more rainfall. Are any facts known which substantiate this belief?

On the contrary, everything points to the fact that three hundred years ago the climate was the same as it is now. - There seems to be a simple proof of that. One of the few important export products appears to have been pockwood (the wood of the 'lignum vitae' tree, Guayacum officinale, Dutch: pokhout). Now, everywhere where this tree abounds it is a sure sign of drought conditions. (This, of course, does not mean that it does not thrive in a wetter climate. In fact, it grows better on a lot of water that on just a little; but whereas in a dry climate it will have an edge on 
less drought-resistant species, in humid areas it cannot hold its ground against other trees which grow faster.) - The alleged beneficial influence of forestation on rainfall is based on a theory which now seems to have been discarded. But even if this theory were valid for large land-masses it is a priori improbable that it would be so for a small island like ours.

64

Is it to be inferred from the above that the vegetation has always been more or less the same as it is now?

By no means! Man has had a thoroughly devastating influence on the vegetation of the island. The primary forest has been felled

a) for home sites;

b) for purposes of cultivation;

c) to export valuable wood: pockwood (Guayacum officinale) and logwood (Haematoxylon brasiletto, Dutch: verfhout, brazielhout);

d) for charcoal burning;

e) for immediate use as fuel;

f) for lime burning.

But has not the vegetation restored itself after the felling of the trees ceased and cultivation stopped?

Restoration to the original condition, even if the process were allowed to proceed undisturbed, would take many centuries.

At the moment the situation is as follows. Scores of hills are naked or nearly naked. On others there has developed a 'secondary growth' which varies considerably from place to place. Often herbaceous shrubs, such as 'willensalie' (Croton flavens), 'flaira' (Jatropha gossypifolia) and cacti, are the first to appear. At places with more moisture 'palu di lechi' (Cryptostegia grandiflora) is a scourge and chokes every decent tree which might try its chance. At best we get a 'secondary forest' in the valleys and lower hills with 'divi-divi' (Caesalpinia coriaria), 'wabi' (Acacia tortuosa), 'watapana shimarón' ('mata di galiña', Acacia villosa) and 'indju' (Prosopos juliflora).

66

It is widely assumed that a great deal of the blame for the deforestation of Curaçao has to be put on the goats. Is that so?

A sweeping statement like that is very misleading. The situation is not quite so simple. First and foremost, man has to be blamed. - In forested areas which have not (or only moderately) been disturbed by the predatory activity of man there is no sign of any serious denudation, even when large herds of goats are kept. Good examples are the areas of Wacao, Zevenbergen and St. Christoffel, which are largely covered with thick, nearly impenetrable forest.

In fact it is surprising how little barren ground there is on Curaçao, in places where man has not destroyed the original vegetation too much. In drought periods, when the trees and shrubs lose all or most of their foliage, 
there is a superficial impression of barrenness. In any good rainy season, however, we observe a forestation of such abundance that we greatly wonder how all these trees and shrubs could have survived the preceding severe and long-sustained periods of drought, and why they have not killed each other in mutual competition for the little moisture left in the soil.

67

Assuming that the goat cannot kill a full-grown tree, as he is not able to nibble at the higher branches, is it not incontestable that he will destroy all young trees, and in this way impede any new growth of trees on denuded soil? And would not the naked or cacti- and croton-infested hills (formerly denuded for cultivation but now lying waste) grow a secondary vegetation of trees if goats were banned?

Again, a general statement of this kind cannot be accepted. The remarkable thing is that the valleys adjoining the same hills are often overgrown with impenetrable secondary forest of 'divi-divi', 'wabi' or 'indju'. The I50 ha (425 acre) plot near Julianadorp (the northernmost part of the former plantation of Groot Piscadera), which was denuded (allegedly for water-conservation purposes!) fourteen years ago, is now overgrown with a large number of wabi trees up to $3 \mathrm{~m}$ high! It seems that in places where enough topsoil is left and the moisture content is great enough, secondary growth of trees can be expected notwithstanding the presence of goats.

68

But the 'wabi' is a tree with large thorns, and for that reason perhaps is not entively destroyed by the goat?

Thorns seem not to be absolutely indispensable to enable a young tree to survive the attacks of goats. For example, in the area of Korporaal (opposite Zuurzak), whereas the higher hills are nearly absolutely barren, the lower ones carry many small divi-divi trees. And in the adjoining area of Bottelier, which was stripped of its vegetation approximately four years ago, many small divi-divi trees are also struggling ahead. In other places, abundant new growth of the equally thornless Acacia villosa or of Prosopis juliflora, indju or qui (with only small thorns) can be seen. In all these areas there are many goats.

69

May the goat then be absolved of the sins which are charged against him?

Only partly! There are young trees which doubtless will succumb if not left alone by goats. For example: that pockwood (Guayacum officinale) can be actually prevented from spreading by goats was clearly demonstrated on Blauw plantation. Near to the beach of Blauw Baai (which is a limestone plateau) there was a little house surrounded by some fenced-off ground. Inside and outside the fence there were a few large 'lignum vitae' trees. Whilst, however, inside the fence there were numberless small saplings, apparently grown from falling seeds, outside of it there were 
only a few, and those showed clear marks of 'nibbling'. Apparently most of the young, very slowly growing trees succumb to the attacks of browsing animals. Quite contrary to popular belief, cattle do eat pockwood leaves, at least in periods of severe drought. - The garden of the Curaçao Museum and some gardens on Scharloo (all unirrigated) are further proof that pockwood will spread profusely when goats are absent.

$$
70
$$

Does the goat do any considerable damage to the grass cover?

In the dry months there is little sign of any 'grass cover', but as soon as the rains start we see an abundance of grass growing on many barren places. The roots survive even after long spells of drought. There seems, however, to be a marked difference between places where goats abound and fencedoff areas, which provides strong evidence for the belief that goats are detrimental to the growth of grasses (perhaps by tearing out the roots?), though some observations in dry regions in Africa do not substantiate this belief (see Edwards: E. Afr. Agric. Journal, 1948, p. 223).

$7 \mathbf{r}$

So the damage done by goats depends very much on the type of plant concerned and probably on many other factors?

Quite so! It can even theoretically be inferred that in some cases the goat may have a beneficial influence!

Let us assume that I have a plant growing in a concrete trough, in a certain amount of soil (evaporation direct from the soil is prevented by a layer of plastic foil). After the soil has been provided with plenty of water, my plant will burst forth, producing luxuriant foliage which will evaporate a lot of water. If I do not replenish the water quickly it will soon be used up completely, and the leaves will wilt; and if I keep on with my experiment the plant will die. Now suppose I clip off part of the foliage; less water will be evaporated, the moisture in the soil will last longer, and my plant will survive a period of 'drought' which would have killed an 'unclipped' plant. Of course, this is only a 'theoretical' possibility (which, however, is by no means contradicted by the facts), only serving to emphasize that no general statement is possible; many plants may be seriously hindered by foraging goats, while some others, in certain particular circumstances, may eventually be helped.

$$
72
$$

It has repeatedly been emphasized that a law should be promulgated establishing the right of the Government to control the grazing of small livestock. Why has this not been done?

Theoretically, this is very easy. If every goat caught on land which is not the owner's is forfeited, goat-keeping by people who do not possess the land to sustain their animals will soon cease. However, the goat is the poor man's moneybox. It is possible to keep some small livestock with only a little trouble. When the owner needs some extra cash (for a feast, to pay the doctor, etc.), he will sell a goat or two. 
It has also been repeatedly proposed that a method of 'alternate grazing' should be applied. This means dividing the grazing grounds into plots. If we have, for example, five plots, one plot will be grazed this year and the others will have time to 'recover'. Next year the next plot will be used, etc. Why has this method never been tried here?

This recommendation is typical of people who do not know the actual situation here. First of all the method would be utterly impractical. There are no well-defined 'grazing grounds' for the poor man's goats. They browse along the roads, on a little tract of government land here, another little or larger tract of private, unused land there. Moreover, to carry out such a recommendation (if possible) might have precisely the reverse effect. Confinement of many goats to successive small pieces of land could result in the utter destruction of all small trees 'beyond recovery'.

74

Again, it has been recommended that the extensive method of goat-keeping should be abandoned in favour of an intensive method. So, instead of the goats being allowed to roam about, they should be confined to the owner's land and fed on green food cultivated by him by irrigation methods. Could this be a solution?

Certainly not! Food produced by irrigation is much too expensive for animals bred for meat. Moreover, as irrigation water is so scarce, only a limited number of head could be kept alive in this way. (Cows maintained for the production of milk do get some green food grown by irrigation, but this is only for 'vitamin supply'. They are really kept alive by imported food, and fresh milk produced thus is very expensive.)

75

Some people - or rather many people - seem to expect that fencing off part of a wilderness to keep out all goats will result in a rapid improvement in the pattern of vegetation. Is that expectation by any means justified?

By no means! What happens after a piece of wilderness or denuded area is fenced off depends on very many factors: the amount of topsoil present, the structure of the subsoil, the ground-water level, the moisture-absorbing capacity of the soil, the topography bearing on the hydrological situation, the vegetation already present (which will yield seeds for new growth), etc. In many cases, very little change would take place, at least not perceptibly within a reasonable period. In the long run there may be more vegetation, or the type of vegetation may alter. Any such change, however, would be very slow!

$$
76
$$

Assuming that there is a basic possibility of improving the pattern of vegetation, but that this would take a very long time if left to nature (after banning the goats), would it not be possible to accelerate the process by human intervention, that is to say by reforestation? 
There is much glib and unrealistic talk about reforestation. It is very easy to cry fie and shame about the really terrible state to which the island's vegetation has been reduced, to demand that 'something be done about the situation', to point to the fact that in Israel or some other country success has been achieved with tree planting, etc. However, to prove the practical feasibility of reforestation under the particular conditions existing here, we have to come down to hard facts. We have to visualize which areas we want to use, which trees we would choose for each particular site, how (eventually) we keep out the goats, which techniques of site preparation have to be chosen, how we help the young plants through severe drought periods, how we prevent them from being choked by 'weeds' like 'willensalie' (Croton flavens), 'flaira' (Jatropha gossypifolia), 'palu di lechi' (Cryptostegia grandiflora) or 'uña di gatu' (Mimosa distachya), whether and how it is possible to keep the cost down to reasonable proportions, etc.

Each one of these problems is fraught with difficulties and calls for study and experimentation. Above all, however, we need the advice and judgement of people who, through long experience, have an intimate knowledge of the indigenous vegetation; who know why certain plants grow on certain sites and not on others; who can give an opinion about drought-, salt-, wind- and goat-resistance of the plants, about their speed of growth, crown development, shedding of leaves, methods of propagation, etc.

Realizing the difficulty of fencing off a large tract of Government land and keeping it fenced off (the goat owners always try to cut the fence to let the goats in), Mr. E. J. vAN DER KUIP, Aruba's Government veterinary officer, proposes to plant young 'indju' trees (Prosopis juliflora) in the good years of the rain cycle, without any fencing. The experiment is worth trying, but success depends very much on the site chosen. On flatlying, friable, water-retaining soil growth can, of course, take place much faster than on rocky hillsides. In fact, on these last locations growth will be very slow indeed.

On the bare Curaçao hills (as examples of which, the higher hills on Korporaal were mentioned), it is improbable that success will be attained without 'ringing' the hills (see later). Perhaps in these cases we ought to think about trees which are even more drought-resistant than 'indju'. In this respect, pockwood (Guayacum officinale) is the champion. Due, among other things, to mechanisms by which evaporation of water through the leaves is reduced in the extreme, this tree retains its foliage in full glory throughout the severest droughts. However, its growth, especially on dry hillsides, is very slow and - as previously pointed out the planting area should be fenced off. Balanites aegyptica (corona di hesus), Zizyphus spina-christi (apeldam), Prosopis juliflora (indju), Acacia tortuosa (wabi), Pithecellobium unguis-cati, and perhaps some other carefully selected trees, might do without any fencing. - If we do not insist on leaf-bearing trees, euphorbias, agaves and aloes can, of course, be used.

Could perhaps the reforestation of naked hills be profitably combined with erosion control by low dams such as have previously been discussed? 
The trenches in front of the dams would certainly be the best places to plant trees for reforestation, but they are also good places for Mimosa distachya, Croton flavens, Jatropha gossypifolia and Cryptostegia grandiflora, which, once they get a foothold, will tend to choke the young trees.

78

But if the hills were formerly forested, why not simply choose the same species which constituted the original vegetation?

This is not quite so simple as it looks. It is very difficult for any young tree, with its shallow root system, to establish itself on a naked, windswept and shadeless hillside without a layer of good topsoil, and still more difficult for it to maintain itself against the competition of some hardy shrubs, such as those just mentioned, which do not need a forest habitat in which to thrive.

79

What requirements must a tree satisfy in order to be used for the reforestation of hillsides?

The following factors, among others, are of importance: $a$ ) resistance to drought; $b$ ) ability to retain its foliage or parts thereof during drought periods; $c$ ) resistance to wind; $d$ ) speed of growth; $e$ ) resistance to attack by goats; $f$ ) ability to resist weeds when young; $g$ ) beauty.

It is very possible that we shall not find any one tree which fulfills all these requirements, and we should content ourselves with a combination of trees, some of which have certain and others other good qualities. - First of all, we have to make a thorough search in the stock of indigenous wild trees which we possess. However: 'the proof of the pudding is in the eating', and we shall have to do quite some experimenting.

\section{0}

What about the use of agaves and cereus cacti? This is not actual reforestation, but surely it is better than naked hills?

There are several kinds of nice agave and cereus species, and they might certainly be tried out.

$8 \mathbf{I}$

Which areas on the island could be designated for reforestation?

This is a difficult question. The areas which need reforestation most are those in the 'second district' (= the eastern part of the island, with the exception of Willemstad, which town may be called the 'first district'), around the Schottegat. Nearly all, however, are private property. As they are situated near the city they would be expensive for the Government to buy and, moreover, they are in danger of being parceled out and used for building sites at any moment. - In the third district ( = the western part of the island) there are, of course, also hills which have been denuded, but many of those which are not cultivated have established a secondary vegetation. It may be dangerous to tamper with this secondary growth, so such hills had better be left alone. 
If the reforestation of denuded hills is so difficult, would it not be possible to start with a carefully selected valley where the circumstances are particularly favourable?

One such area might be - ironically enough - the 150 -ha (425-acre) stretch of flat land near Julianadorp mentioned before, which was wilfully deforested about 1946 for the alleged purpose of water conservation. The area was densely wooded; there is a deep layer of good topsoil; there are several wells provided with windmills on hand and three dams. - Another area would be the Government-owned Klein Kwartier, at present also for the most part denuded of trees. If Shell and the Government would stop ground-water extraction in these places there would be ideal opportunities for creating park-like reforested areas.

As already pointed out, at the present time the Shell area is overgrown with 'wabi' trees (the heavily spined Acacia tortuosa) and, on the moistest places, with a nearly impenetrable tangle of 'palu di lechi' (Cryptostegia grandiflora), the rubber-containing shrub with its twining branches and its faintly violet, trumpet-shaped flowers. In some places the poisonous Hippomane mancinella (manzanilla) occurs. - The following trees could be considered for reforestation of this area: Albizzia lebbeck (barba di jonkuman), Balanites aegyptica (corona di hesus, lamunchi shimarón), Bontia daphnoides (olijfi), Bursera bonairensis (palu di śa corrá), Bursera simaruba (palu di sía blancu), Bursera tomentosa (takamahak), Bumelia obovata (placa chiquitu, rambèshi, palu di lechi), Caesalpinia coriaria (divi-divi, watapana), Caesalpinia pulcherrima (tuturutu), Ceiba pentandra (katunbom), Conocarpus erecta (manguel blancu), Coccoloba uvifera (dreifi, sea grape), Coccoloba diversifolia (kamari), Cordia sebestena (cawara spaño), Cordia alba (cawara di mondi), Crescentia cujete (calbás, calabash), dwarf coconut, Delonix regia (flamboyant), Eucalyptus robusta, Ficus brittonii (mahok di mondi), Ficus benjamina (waringin), Ficus elastica, Ficus heteromorpha, Ficus retusa, Ficus urbaniana, Gliricidia sepium (mata raton), Guayacum officinale (pockwood, lignum vitae), Malpighia punicifolia (shimarucu), Moringa oleifera (benbom), Peltophorum inerme, Pereskia guamacho, Prosopis julifora (indju), Phoenix dactylifera (dader, date), Samanea saman (rain tree), Swietenia mahagony (mahok, mahogany), Terminalia catappa (almond tree), Spondia lutea (hoba, yellow plum, hog plum), Tabebuia crysantha (kibrahacha), Tabebuia pallida (white cedar), Tabebuia pentaphyl la, Tamarix gallica, Tamarindus indica (tamarind), Tecoma stans (kelki geel), Zizyphus spina-christi (apeldam). - Of course, the areas would have to be well fenced off, and a supervisor would have to live there.

With the help of a little irrigation it should be possible to have a nice young forest with quite some shadow within, say, seven years. Fastgrowing species which will be of much assistance in achieving a quick result are Albizzia, Crescentia, Delonix, Peltophorum suringari, Gliricidia, Zizyphus, and the Ficus species mentioned. - Naturally, the wabi trees now growing in the Shell area should not be cut down at once, but only gradually, as the other trees grow up. Eradication of the 'palu di lechi', however, would be necessary and may prove to be a tough job. - If this scheme were to succeed, the cutting-down of the original forest near 
Julianadorp would be vindicated to some extent, for its former tangle of trees and shrubs would have been transformed into a recreational area with nice shady trees, under the crowns of which it would be pleasant to walk and sit. But this achievement would be neither easy nor cheap!

83

Presumably there are some plants which are not eaten by goats. Could these be used profitably for reforestation?

There are more plants which are not attacked by goats than most people realize. They may contain a milky rubbery fluid (a) or irritating substances (b) or be covered with thorns (c) or have a bitter or otherwise unpleasant taste (d).

The following plants of Curaçao belong to this category:

Trees: many Ficus species (a), Thespesia populnea (otaheit) (d), Capparis species (oliba, palu pretu) (d, probable), Jacquinia barbasco (mata di pisca) (d), Hippomane mancinella (manzanilla) (b), Conocarpus erecta (manguel blancu) (d, prob.), Coccoloba uvifera (dreifi) (d, prob.), Coccoloba diversifolia (dreifi shimaron) (d, prob.), Casearia tremula (palu di Bonaire) (d), Plumeria species (oleander) (a), Beureria succulenta (watakeli) (d, prob.).

Shrubs. Croton niveus (lumbra blancu) (d), Bontia daphnoides (olijfi) (d), Suriana maritima (d), Nerium oleander (Franse bloem) (a), Calotropis procera (katuna di seda) (a), Thevetia peruviana (a).

Cacti. Opuntia, Cereus-like and Melocactus species (c).

Euphorbias. Euphorbia cotonifolia (manzanilla bobo) (a), Euph. buxifolia (a), lactea (cactus Surinam) (a), nerifolia (cordon santu) (a), tirucalli (potloodplant) (a), splendens (corona di sumpina) (a), pulcherrima (poinsettia( (a), and several small 'herbaceous' euphorbias.

Miscellaneous. Agave and Aloe species (d), Vinca rosea (madalena) Hymenocallis caribaea (leli) (d), Lantana camara (flor di sanguer) (d), Croton species (welisali) (d), Jatropha gossypifalia (tlaira) (b), Cryptostegia grandiflora (palu di lechi) (a), and Datura species (d).

There are a number of plants which, though the leaves are highly palatable to goats, still manage to survive their attacks fairly well, e.g. Caesalpinia coriaria (divi-divi) and Prosopis juliflora (indju or qui). These trees, being by nature deciduous, do not suffer too much when robbed of all their foliage during drought periods. A tree like Guayacum officinale (guayaca), however, being non-deciduous, succumbs when deprived of its leaves for a long time. - Which of the above-mentioned plants can be used for planting can only be estimated by a careful study of the sites and the circumstances for each particular case.

84

Speaking about eradication of weeds, there seems to be a caterpillar which has been used with good results in Australia to combat the very obnoxious Opuntia cactus. Why could it not be imported here?

Certainly success has been attained in this respect with Cactoblastis cactorum. However, the troublesome Opuntia is the last 'resort' of the cattle 
owner in periods of prolonged drought. It is fed to the animals after burning off the thorns! Destroying the opuntia would mean destroying the 'iron ration' of the cattle breeder.

85

Would it not be possible to introduce foreign plants which are better suited for reforestation purposes than the indigenous ones?

Some people expect miracles from 'new introductions', but we have to keep in mind the fact that our own plants have adapted themselves to the specific conditions prevailing here in a very long evolutionary process. While we have to look at them first and foremost, this does not, of course, mean that new introductions might not be valuable. To find really good ones, however, requires much experimentation and time. In our three and a half centuries of colonization a lot of this experimentation has been going on, and many obviously adequate species have been introduced, nearly all of them, however, only for cultivation (ornamental or other purposes).

It may be emphasized that introducing a foreign species for cultivation is something quite different from introducing it for reforestation, in which last case it has to fend for itself without help (or with only a little help) from man. A good example of a tree which has been introduced and is doing well in a semi-wild state is the tamarind, whilst e.g. Balanites aegyptica (corona di hesus) and Zizyphus spina-christi (apeldam), both from the Middle East, have gained a firm foothold in very many places.

86

How can all this talk of reforestation be reconciled with the recommendations given in the hydrological report which appeared in 1949? After an extensive expert study of the hydrological situation, not reforestation but deforestation was recommended! Now, who is right, the authors of the 1949 'Krul Report', or the advocates of reforestation?

Everywhere and always, reforestation is regarded as the first prerequisite for water conservation, and infinite pains are taken to achieve this end. Curaçao is probably unique in all the world in that experts have recommended tree felling for water conservation.

\section{7}

Why is the influence of vegetation on water conservation regarded as beneficial?

This influence is considered beneficial for the following reasons:

a) The network of roots binds the soil together, thus preventing erosion (washing-away of the humus-containing topsoil with high water-retaining capacity).

b) The vegetation breaks the impact of hard rain, which tends to aggravate erosion.

c) It provides organic matter which enriches the soil with humus, thus improving its penetration, absorption and retention capacity for water. 
d) It provides shade for the soil, greatly reducing evaporation and protecting the humus from the destructive action of direct sun rays.

$e$ ) It acts as a windbreak, preventing wind erosion and reducing evaporation.

But if there were no negative sides to this picture, how could the authors of the 1949 'Krul Report' ever have recommended destruction of the vegetation so emphatically?

Decidedly there is a negative side. The vegetation does use up a lot of water; this is undeniable. But, on striking the balance, it is accepted almost as an article of faith by all hydrologists that the favourable influence of vegetation on water conservation outweighs its unfavourable influence, not to speak of its aesthetic value (recreation, tourist industry). - Moreover, it has to be borne in mind that the plants, being adapted to an arid climate, all have mechanisms which greatly reduce their water consumption, especially during periods of drought. Shedding of leaves, small leaves, waxy layer on the leaves, folding of the leaves, small stomata, reduced number of stomata, closing of the stomata, are all part of these mechanisms. - The authors of the 'Krul Report' do not seem to have had much understanding of drought-resistant plants. They repeatedly say that the cactus is a deep-rooting plant which extracts much ground water. It need hardly be said that, much to the contrary, the cactus is the classic example of a shallow-rooting plant with extremely small water consumption, which certainly does not use up one drop of 'ground water'.

89

But in the 1949 report the endeavour was made to give a quantitative picture of the harm done by the vegetation to water conservation, by extensive and careful calculations. What is wrong with these calculations?

To draw up any quantitative picture of the infiltration of water into the soil, the flow of underground water, the storage capacity of the subsoil, the influence of evaporation by direct exposure of the soil, the evaporation by the vegetation, the influence of dams, of goats, etc., a great variety of data would have been necessary, based on careful, systematic observations and experiments throughout many years. These data being virtually non-existent, the researchers used estimates, which can only be called wild and arbitrary guesses, and which, in many instances, betray the superficiality of their knowledge of the country (the entire duration of their stay in the Netherlands Antilles was four months). It may be stated that the report was prepared with a lot of intelligence but little wisdom!

90

What were the main conclusions and recommendations in the report concerning the relation between ground-water extraction and vegetation?

The main conclusions were the following:

a) The quantity of ground water pumped out of the wells is small compared with the quantity used up by the vegetation. 
b) The influence of ground-water extraction on vegetation and groundwater table is small.

c) There is no need to stop or reduce the extraction of ground water.

d) If necessary, the withdrawal can be stepped up.

e) The water table will rise as a result of deforestation; this has to be done to help the water supply system of the Government and Shell.

f) Areas where no ground-water extraction for the Government Water Supply System had yet been practised (third district) could be tapped, if necessary.

g) Deforestation, which is recommended, will not increase erosion appreciably.

Curaçao can consider itself fortunate that these recommendations of the report were not carried out, though they have done considerable damage by delaying any action to stop the ground-water extraction.

9I

Is much deforestation still going on in the island?

Deforestation for agricultural purposes, for charcoal burning and for lime burning has virtually stopped. For the preparation of housing sites, of course, stretches of land are cleared regularly. It is a pity that frequently this clearing is not done very judiciously, so that many trees are felled which could have been spared. Often much more land is cleared than can be sold in many years to come, so that this land is lying waste and is prone to erosion.

Again, a silly prejudice against manzanilla bushes sometimes leads to their destruction. To be sure, the manzanilla is poisonous, and the skin of sensitive people may become severely irritated when the wet leaves are touched; but everyone knows this, and accidents are very rare, even at places which are very much frequented by children (such as the beach at Piscadera Bay). On the other hand, manzanilla trees are excellent for shade and often act as windbreaks. Since the manzanilla bushes east of the splendid fruit grove of Santa Cruz were cleared away a few years ago, serious damage has been done by the wind to the front rows of mango trees - Very recently the manzanilla bushes at Ronde Klip were cut down by the Government organisation for relief work, out of misdirected zeal to 'save' the remnants of the old fruit grove. Well might these remnants muse: 'God protect me against my friends'. The manzanilla haters do not seem to understand that, whilst it is very easy to destroy a lush stand of these trees, it is extremely difficult - and in most cases so expensive and time-consuming as to be virtually impossible - to artificially establish a vegetation of 'better' trees instead. Destruction of manzanilla trees may be necessary, e.g. when they tend to suffocate fruit trees; but such destruction has to be carried out very judiciously. - Again, enthusiasm in 'clearing' roadsides prevents the growth of shade trees which would spontaneously establish themselves if left alone. In and next to trenches (for drainage) beside the roads, many young indju trees try their luck. Whilst, of course, it is essential to remove the trees in the trenches, those alongside should be left alone! By following this simple policy, in time the roads in the residential areas would be lined with these providers of shade. It has to be borne in mind that conditions for growth are favourable along the paved roads, with their high run-off. 
In the foregoing it has been stated that in order to get a dependable picture of the hydrological situation many more data would be necessary. Are geological data very important in this respect?

Geological data are certainly important. A lot of geological surveying has been going on during the last hundred years, but only on the surface. As already indicated, the structure of the subsoil of Curaçao is extremely complicated. Drillings could give an idea of what is going on under the ground.

In the foregoing it has repeatedly been said that agriculture on Curaçao is having, and has always had, to fight against great odds. Nevertheless, it was contended that formerly it was of considerable importance for the inhabitants, though it is of very little importance now. How can this be explained?

First of all, we have to consider the vast difference between the economy and the standard of living of the average person now and formerly. The average standard of living before the establishment of the oil refinery was very low indeed compared with what it is at present, and a little produce from the land means a lot to people living a marginal existence. Secondly, we have to take into account the phenomenal increase in the population. From 30,000 forty years ago it has jumped to nearly 130,000 now. But let us try our hand at some calculations.

A recent aerial photographic survey showing us the deforested areas which are supposed to have been cultivated formerly, and the topographical map of rgro, which shows us the areas that were provided with dams, enable us to make a very rough estimate of the acreage under cultivation. From this it can be deduced that a total of perhaps 5,000 ha $(12,500$ acres) was used for sorghum. Unfortunately, there are no reliable estimates as to the average yield per ha. Generally speaking, 4,00o kg per ha under favourable conditions can be considered a good yield. Taking into account the quantity which is needed for seeding, and the losses incurred through insect pests, parakeets and doves, maybe 3,000 kg remains as net yield. This is a 'good' yield, a 'fair' net yield being perhaps $2,000 \mathrm{~kg}$ per ha. If we take one 'good' and one 'fair' yield in a six-years rain cycle, we get $5,000 \mathrm{~kg}$ per ha, meaning a total harvest of about 25,000 tons per six years on the entire island, or an average of about 4,000 tons per year. If we now assume that, of the 30,000 inhabitants, ro, 000 living in the city were totally independent of agriculture (the mainspring of their livelihood being the trade and harbour activity of Willemstad), then every one of the 20,000 remaining people could get a ration of $200 \mathrm{~kg}$ sorghum per year, or more than $\frac{1}{2} \mathrm{~kg}$ per day. - Even if this figure is too high and should be halved, it would signify a marginal subsistence level when supplemented with home-grown beans and vegetables (grown by irrigation), goats' milk and meat from own goats, sheep, pigs, fowl and casual wild iguanas and self-caught fish. Money for buying imported dried fish, fish from local fishermen, clothes, corn meal (maize) and beans was obtained by selling to the city poultry, eggs, small livestock, some vegetables, fruit and peanuts. - The value of the 4,000 tons of sorghum produced yearly 
(on an average) would be - at present-day prices - about NA $f \mathrm{I}, 200,000$.

As regards other agricultural products, it is really very hard to make an estimate. The nearest we can get to doing this is to establish an 'order of magnitude'. Statistics for the number of goats, sheep and pigs raised on the island are non-existent. Figures which we encounter in various publications are at the most 'guestimates'. If we take a 'guestimate' of a goat population of 30,000 , of which $10,000-15,000$ are consumed, this makes about $f 300,000$ at present-day value. - The production of beef and pork, goats' and cows' milk, poultry, eggs, vegetables and fruit is even more difficult to estimate. But, all in all, the total value of the agricultural production could not have exceeded a few million guilders (present-day value) per year. - The plausibility of this assumption can also be confirmed by another kind of reasoning. Let the value of the agricultural production be $f_{4}, 000,000$ per year. We have assumed 20,000 of the 30,000 inhabitants to have been dependent on agriculture. This would mean an average annual income of about $f 200$ per person, or about $f \mathbf{1}, 200$ per average family.

It is obvious that, in those times, with the people's life as simple as it was, this income could not have been more. $F$ 200 per year is $f 0.55$ per day. If the average daily consumption of cereal meal is $\frac{1}{2} \mathrm{~kg}$, at a value of $f$ o.15, $f 0.40$ is left for the rest. This rest is nearly exclusively nutrition. Clothing was exceedingly simple (virtually no footwear, or else self made footwear, little underwear) ; transport did not cost anything (long distances being covered by foot or otherwise on a home-bred donkey); housing was gratis (self-built daub and wattle huts); furniture virtually non-existent or self-made; and amusement a communal affair. Tobacco and rum were almost the only luxuries.

If we compare this picture with the situation as it is now, the following can be remarked. - From the foregoing it is apparent that the region most intensively cultivated was the 'second district', which is the area around and in the neighbourhood of the Schottegat, Spaanse Water, St. Joris Bay, Jan Tiel Bay and Piscadera Bay, and which, as already stated, contained a thousand dams, which is more than two thirds of all the dams on the island. Nowadays, in this region agricultural activity has been reduced to a very small fraction of what it formerly was. The reasons have already been expounded above: use of land for industries, housing sites and roads; 'salting-up' of the valleys by the penetration of sea water; employment of the inhabitants in industry and trade.

In the 'third district' only the last factor has been active (even people living in 'Westpunt' are daily picked up by bus to work in the city!). But its influence has been great enough to put an end to most agricultural activities there as well. Let us take a closer look at the situation as it is at the present time:

I) Planting of sorghum, beans, peanuts: a vast decline.

2) Horticulture: virtually only in a few irrigated gardens, by Chinese and Portuguese.

3) Fructiculture: nearly wiped out by the decline of fruit groves, as extensively explained before.

4) Cows, goats, sheep, pigs for meat: probably not declined.

5) Poultry and eggs: probably increased, but dependent to a large extent on imported chicken feed. 
6) Milk from goats and sheep: not produced any more.

7) Milk from cows: has probably increased, but to a very large extent dependent on imported food. A 'luxury item', very expensive.

94

With the economic situation deteriorating and unemployment increasing, would it not be possible to restore agricultural production to its former level, or even surpass this level?

Let us consider the situation in detail! To answer this question we will use the classification of agricultural production just given.

I) The production of sorghum (grain), beans and peanuts is only economically feasible without irrigation. In the second district, large plots of the best land have been lost to industry, housing sites and roads, and the intricate system of dams has broken down 'beyond repair,' as previously explained. Owing to the population pressure, land which could still be available for planting will be needed for housing sites in the near or little distant future. - There is not much sense in trying to bring this land back into agricultural use. In the third district there is indeed a possibility of doing so (if we disregard for a moment the psychological and economic difficulties), but we could not hope for more than 2,000 ha, taking into account the fact that we have to carefully avoid any tampering with the forestation of the steeper hills (such as those of Groot St. Martha, Zevenbergen, Savonet, Wacao and Knip).

2) In contrast to the production of staple foods (sorghum, beans), which can only be practised in the wet seasons of the 'good' years of the rain cycle, horticulture can be a year-round business. The yield in money per $\mathrm{m}^{2}$ is very much higher than from the production of staple foods, so that the cost of irrigation can be easily afforded. The surface of land needed is comparatively small, and hence even in the second district there would be enough land to meet a great proportion of the demand on the island (e.g. Klein Kwartier and the deforested plain of Groot Piscadera). - If the Government and Shell were to stop pumping, a thousand tons of well water per day could be used for horticultural purposes and would suffice for about 50 ha.

3) In the second district a large part of the valleys best suited for fructiculture has been spoilt by the infiltration of sea water (it has already been said that this has occurred all around the Spaanse Water, Jan Tiel Bay, Schottegat and Piscadera Bay). Other such valleys have been used for building sites (e.g. Isla, Rio Canario, Julianadorp, Van Engelen, Cas Corá, Groot Kwartier, Zeelandia, Poos Cabaai, Mahaai, Damacor). In the third district the number of groves has been much smaller than in the second district, most of the existing ones having deteriorated through neglect (breaking of the dams, encroachment of manzanilla). - In principle there are possibilities of:

a) keeping the still more or less 'flourishing' groves in good condition (e.g. St. Joris and Choloma in the second district, St. Cruz in the third district);

b) trying to save the ones which are threatened, by stopping groundwater extraction by Government and Shell and/or repairing the dams and/or replanting trees (e.g. Groot Piscadera, Rooi Catootje, Brakkeput, 
Scherpenheuvel, in the second district; Groot en Klein St. Martha in the third district).

c) Replanting the groves which have died (restoring dams, irrigation systems etc.) or creating new ones. For the time being, and probably for quite some years to come, this will only be possible on that ground which has not been spoiled too much by the infiltration of sea water (e.g. in the second district: Ronde Klip, Hato Mansion, Blauw, Klein Kwartier, St. Michiel, the northern deforested plain of Groot Piscadera, Malpais; and in the third district: Ascencion).

The economic side of these 'possibilities' will be dealt with later on.

In the following I have tried to compile a list of the most important fruit groves which existed in the first decades of this century, with details of their condition at the present time. This list is the result of only a cursory examination, and it would certainly be advisable to make a more detailed inventory. Of course, there were formerly several other small groves, a few of which still exist but do not appear in the list. - In perusing this compilation it has to be borne in mind that at one time most of these groves were also connected with horticulture and sometimes with dairy activities. (See the map on p. 198.)

Name

Present condition

(Second District)

Klein St. Joris

Choloma

Groot St. Joris

Santa Barbara

Wilhelminapark

Koraal Tabak

Santa Catharina

Jan Zoutvat

Brakkeput Ariba

Brakkeput Meimei

Brakkeput Abau

Jan Tiel

Bottelier

Zuurzak

Scherpenheuvel

Korporaal (several)

Ronde Klip

Bonnam

Maria Maai

Brievengat

Semi-Kok

Jongbloed

Zapateer

Janwé

Vredeberg

Bloemfontein

Klein Davelaar

Groot Davelaar

has suffered badly.

good.

good in part, rest has suffered badly.

dead, completely; encroachment of sea water.

good.

dead.

has suffered considerably.

dead.

is beginning to suffer.

is beginning to suffer.

is beginning to suffer.

has suffered very badly.

still fair, but suffering.

nearly gone; encroachment of sea water.

nearly gone.

nearly all gone.

nearly all gone.

still fair, but suffering.

dead.

dead.

dead.

dead.

dead.

dead.

nearly gone.

dead.

dead; encroachment of sea water.

dead; encroachment of sea water. 
Name

Girouette I

Girouette II

Zeelandia

Pos Cabaai

Zuikertuintje

Rooi Catootje

Mahaai

Cerito

Bloemhof

Jonchi

Klein Kwartier

Gaito

Groot Kwartier

Van Engelen (several)

Urdal

Cas Corá

Marchena

Veeris

Raphael

Klein Piscadera

Groot Piscadera (high)

Groot Piscadera (low)

Blauw

Groot St. Michiel

Klein St. Michiel

Malpais

Hato

Papaya

(Third District)

Hermanus

Rif

Villa Maria

Jan Kok

Siberië

San Pedro

St. Jan

Ascencion

Zumbu

Patrick

Groot Santa Martha

Klein Santa Martha

St. Nicolaas

Santa Cruz

Savonet

Barber

\section{P. C. HENRIQUEZ}

Present condition

dead.

still fair.

dead; encroachment of sea water.

dead; encroachment of sea water.

nearly all gone; encroachment of sea water. critical; encroachment of sea water.

nearly all gone; encroachment of sea water. dead; encroachment of sea water.

has suffered considerably.

nearly all gone; encroachment of sea water.

dead.

dead; encroachment of sea water.

dead; encroachment of sea water.

nearly all gone.

dead.

nearly all gone.

dead.

dead.

suffering; encroachment of sea water.

dead; encroachment of sea water.

started suffering in $196 \mathrm{I}$.

suffering badly.

died completely in 1961.

nearly all gone.

has suffered considerably.

practically all gone.

dead.

dead.

dead.

dead.

dead.

nearly all gone.

dead.

has suffered very badly.

suffering.

dead.

dead.

has suffered considerably.

has suffered considerably.

has suffered considerably.

fair.

has suffered somewhat, but is still good.

dead.

nearly all gone.

4) Increase of the numbers of animals must be considered virtually impossible. There is already overgrazing, and many perish during drought periods. - Improvement of the quality of the stock has been advocated 
by the introduction of male thoroughbred animals and castration of the indigenous males. The crossbreds may be heavier, but it is not certain that they will produce more meat per pound of food under the conditions prevailing here. On the other hand, it is certain that the crossbreds are less hardy than the indigenous race. 'Big' plantation owners do sometimes import animals to improve their herds. Repeated efforts by the Government in this direction, especially to help the 'small' farmers as well, have failed.

5) Poultry and egg production was formerly only on a small scale. With the tremendous increase in prosperity and population, and the demand for their products zooming, several medium-sized, reasonably well-organised chicken farms have made their appearance. The nine largest keep 800-2,000 hens each, with a total of perhaps 12,000-15,000. There are two large broiler farms, one with about I $_{4}, 000$, the other with about 4,000 fowls. In addition, a fairly large number of people keep from 100 to 200 birds, for both meat and egg production. A production of 175 eggs per hen per year is considered to be quite good. - Nevertheless, yearly imports into the island are still more than $500,000 \mathrm{~kg}$ of poultry and more than 300,000 dozen eggs, at a fob value of more than three quarters and one quarter of a million guilders, respectively.

6) Goat's and sheep's milk were formerly in use, but no longer nowadays. There was no question of keeping animals of a special milk-producing breed. The same animals which were kept for meat were sometimes milked. Increase in prosperity, and the introduction of cheap imported condensed and powdered cow's milk, have put an end to this unreliable source of milk. - Keeping goats of a special milk-producing breed seems to make little sense for the small farmer. These goats are not hardy enough to roam about in search of their own food. They have to be properly taken care of and fed with imported food if they are to thrive and produce properly. Time and again the different 'departments of agriculture' which have been organised, functioned a few years, and again disbanded in the course of the last one and a half centuries have attempted to introduce this kind of animal, but without any success.

7) There are several fair-sized dairy farms on Curaçao, some of them very well organised, with highly productive cattle. The stock has to be fed on imported mixed food, and on green food (sorghum) locally produced with the help of irrigation. - There is little scope for expansion in this branch of husbandry. The milk is very expensive ( $f$ o.70 per liter compared with $f 0.35$ for powdered milk and $f 0.27$ for evaporated milk), and is only bought by well-to-do-people who insist on fresh milk.

$$
95
$$

From what has just been said it can be deduced that only in the following fields is there any basic possibility of expansion, to wit: agriculture proper (mainly staple foods: sorghum and beans), horticulture, fructiculture and chicken farming. What economic importance can be attached to these fields; in what way could improvement be achieved; and what role could government intervention eventually play?

Let us try to answer these questions one by one. As already said, production of staple foods is only possible by making use of seasonal rains (irrigation bing too expensive and the quantity of well water available 
too small). It has also been estimated that, of 5,000 ha formerly planted in the second and third districts, only 2,000 ha in the third and perhaps $\mathbf{r}, 000$ ha in the second district could be brought back into agricultural use . The production of sorghun from these fields would have an average value of about $f 750,000$ per year (taken over a six-years rain cycle with two succesful crops). If we add to this the value of beans, squash, watermelons and ochro produced with the help of seasonal rains we may reach perhaps, very roughly speaking, an average of one million guilders per year. - Of course, this figure depends on a big 'if': if we can get enough people back to this kind of not very remunerative, irregular agriculture.

96

Would it not be possible to achieve better results, viz.: to get satisfactory crops oftener than twice in a six-years rain cycle, by using 'dry-farming' methods?

Application of dry-farming techniques has repeatedly been studied, but the prospects offered under the specific conditions existing on the island are far from impressive. For example: deep ploughing and 'mulching', often recommended elsewhere, seem to have adverse instead of beneficial effects here; and 'summer fallow' is of no use (see: report by B. A. BITTER in 'Photo-geological Observations and Land Capability \& Land Use Survey of the Island of Bonaire'). Also, the following has to be kept in mind: the execution of specialized measures for moisture and weed control may be economically feasible when we have large tracts of land with the proper machinery, a tight organisation, and strict central supervision and control of the necessary operations, but is impracticable with little tracts of land each belonging to another farmer and without a central control.

97

But, apart from 'dry farming', are there not other measures which could be taught to the farmers, in order to improve their yield? For example fertilizing, pest control, and selection of better varieties?

These measures necessitate research of long duration and a good organisation with specialists. The money outlay, organisation and time needed are always very grossly underestimated. - The intermittent character of the kind of agriculture which we are considering (twice in a six-years cycle) also makes it exceedingly difficult to achieve any definite results and to keep one's organisation in good shape.

98

Still, it is said that successful agriculture is or has been practised with rainfall figures which are much less than those on Curacao. A striking example is the former Nabatean kingdom in the Negev desert of Palestine. Rainfall is said to be only 5-Io inches yearly but agriculture seems to have flourished!

This is certainly true. Paradoxically enough, this flourishing agriculture was made possible by the vast expanses of naked hills and mountains in the region. The very high run-off of these was collected in a relatively small area with good soil by a highly ingenious system of walls, terraces and trenches. On Curaçao we do not have the large 'collecting areas' or the high and regular run-off! 
With all these things in mind, how could we summarize the situation with respect to the possibility of improvement in this field?

I think we have to admit frankly that, given the psychological, economic and sociological resistance to bringing the people back to unrewarding staple-food production; the low maximum value of the production, even if it were possible to overcome this resistance; and the intermittent and unreliable character of the production, it is very unlikely that government intervention, even if much money were spent on it, would meet with any considerable success.

100

Does the same gloomy prognosis apply to horticulture?

The situation with regard to horticulture is in many respects quite different. Basically the prospects are considerably better. First of all, it is economically quite feasible to practise horticulture with the help of irrigation, and we shall have fairly large quantities of well water at our disposal if the Government and Shell stop pumping. - Moreover, the yield per $\mathrm{m}^{2}$ with rationally practised horticulture is such that even distilled water could be used, e.g. at a cost of $f 0.50$ per $\mathrm{m}^{3}$, which price level will certainly be reached in the not too distant future. (It has already been remarked that the growth of plants, especially during drought periods, will be much better with distilled water than with well water, owing to the latter's salt content.) Hence horticulture can be a year-round business giving reasonable rewards. It is no wonder that it is practised with success by Chinese and Portuguese. Certainly, the market situation warrants a considerable extension.

\section{IOI}

But is it not significant that horticulture nowadays is virtually exclusively practised by Chinese and Portuguese?

It is indeed significant. It reflects several circumstances and facts. Firstly, that considerable skill and long-standing tradition play an important role in successful horticulture. Secondly, that in this field especially, people accustomed to a low standard of living and to working hard in order to earn a livelihood, have an edge on others.

102

That gives a rather dim view of the native inhabitant's prospects of being employed in horticulture, doesn't it?

For the moment, the prospects are certainly not very bright. There might be a change, however, and the Government might try to do something about it. In the last few years some indigenous inhabitants have already been employed by Chinese and Portuguese horticulturists. - What the Government might try to do is to introduce more rational and less back-breaking methods of horticulture than those currently applied. 
What are the rationalisations which should be aimed at?

The most important rationalisations, which seem desirable and possible, are the following:

a) Mechanisation of irrigation, using methods which involve a minimum loss of water. (A 'flat spray' is recommended.)

b) Using plastic-bottomed cultivation beds to further reduce the loss of water.

c) Reducing to a minimum the work of periodical loosening of the soil, and creating the best conditions for growth by improving the soil structure (addition of large quantities of peat moss to the cultivation bed).

d) Using distilled water instead of well water as soon as the former becomes available at low prices. This, of course, has to be seen in the light of the drastic reduction in distilled-water price which has to be aimed at (discussed elsewhere). (It has already been remarked in the foregoing that plants grow much better on distilled water than on well water.) e) Optimal fertilization.

The economic and more detailed technical sides of these improvements have been discussed elsewhere. It suffices to mention here that the investment can be much less than with 'gravel culture', and operation much simpler.

\section{4}

All well and good, but how could people be induced to try their hand at horticulture, using these technical improvements, if they do not even have the basic knouvedge of the 'botanical' side of this accupation.' Would schooling be of any help?

It all depends on what kind of schooling. Organising a kind of 'course' with theoretical lessons would not lead to any success under the prevailing conditions. However, the following solution might be considered. Perhaps a horticultural farm could be set up with the help of the Government and leased to a young, experienced horticulturist from Holland to run for his own account. The people whom he takes into his service would learn by practice.

105

Now, how about fructiculture? Is the situation here about the same as with horticulture?

No, fructiculture has its own peculiar problems. An indication of what could be basically possible to improve the situation has already been given. Let us now consider the economic and practical feasibility of the measures recommended in more detail. St. Joris and Choloma are in good condition. Government intervention does not seem necessary, except perhaps to help the owners to obtain good varieties of trees, and maybe to give them a loan if they want one and submit a sound plan. St. Cruz is very nice; it consists nearly entirely of huge mango trees, which are actually too high to enable the fruit to be collected cheaply. It has little importance for fruit production, but has considerable recreative value. 
It should be bought by the Government for touristic purposes. - Groot Piscadera and Rooi Catootje could perhaps be saved, and Blauw replanted, if a water law was enacted as previously advocated. They are excellently managed.

The groves mentioned are the last remnants of a large number with which the countryside was formerly studded. The quantity of fruit they supply covers only a dwindling fraction of the demand of the island. The problem of how to stimulate the creation of new groves is not easily solved. - This problem is aggravated by the fact that the pieces of land best suited to the purpose have been rendered unusable by encroachment of sea water, as already repeatedly discussed. These were the valleys adjoining the sea, in which the ground-water level was so high as to make irrigation unnecessary for full-grown trees. Hence the eventual creation of new groves can only be effected in valleys at a higher elevation. In most cases these groves would need irrigation at least during the dry season. Well water would be available only if Government and Shell stop pumping.

\section{I06}

Would there be any scope for improvements in the management of fruit groves?

Improvements might entail: careful choice of varieties (special attention should be paid to dwarf varieties, which make picking the fruit so much easier and cheaper), judicious methods of irrigation, proper fertilizing practices. These improvements might help in making fruit-growing a more rewarding business than it is at present.

107

But what could the Government do to stimulate implementation of these improvements?

Perhaps more or less the same course should be followed as already recommended for horticulture, viz: that a man be sought with thorough practical experience of fructiculture and that the Government help him financially to set up a farm along the most modern lines using the best varieties available. - The site should, of course, be carefully chosen. It should have a deep layer of topsoil, the ground-water level should not be too low, and it should be provided with wells with a capacity of, say, 150 tons a day.

108

Isn't it true that the Government had bad experiences some time ago with this kind of arrangement, in which it helped a man to set up a 'model' dairy farm?

Well, technically the enterprise was a big success; a flourishing farm was created. But the juridical side of the contract concluded between the Government and the farmer was quite wrong. The man was provided with a house and a fertile tract of land with plenty of well water. He had to finance all the building-up of the farm himself, but the Government 
paid him a salary 'to instruct the small farmers in the neighbourhood' and was obliged to take over the farm at full value if it wanted to annul the contract. As, however, small farmers to be instructed were nonexistent, the Government decided to cancel the arrangement after some eight or more years, and failed to renew it on a reasonable basis or seek another good tenant. So the farm deteriorated and the Government lost all it had paid for it.

109

In the foregoing it has been said that with horticulture the yield in money per $m^{2}$ is so high that even irrigation with distilled water might be feasible. Does this also apply to fruit-growing?

From fructiculture, the yield per square meter is appreciably lower than from horticulture; hence the water used for irrigation should be substantially cheaper too. - Let us consider, for example, a water price of $f 0.20$ per $\mathrm{m}^{3}$, and let us assume that the grove needs a daily supplement of 30 tons of water per ha for 200 days every year. This makes 6,000 tons per ha per year, costing $f \mathbf{1}, 200$. - It is not easy to estimate at all accurately what value per ha a fruit grove could yield under existing circumstances; much more data would have to be collected to make this possible. According to the best obtainable guess from an experienced farmer this could be around $f 5,000$ per ha. Accordingly, the cost of the water would be a very important item on the budget of exploitation. The good quality of the water, however, may be reflected in the yield and counterbalance this extra cost, at least partly.

I I0

But would it ever be possible to deliver distilled water at a price of $f 0.20$ per $m^{3}$ ?

It has been shown elsewhere that, in the future, if we combine very largescale distillation processes (which are now being developed), and largescale production of electricity, it might perhaps be possible to produce water at a price (at the plant site) of $f 0.20-f 0.25$ per $\mathrm{m}^{3}$. To this, however, we have to add the cost of bringing the water to the grove and of distributing it evenly by means of an irrigation system.

A discussion with Mr. F. FABER resulted in the following idea for reducing the water price even more. During the rainy season, water consumption always drops. The extra capacity of the distilling plant could then be used to produce water for agricultural purposes, which could be sold at differential cost. This differential cost is not much more than the fuel cost, which would be about $f 0.07$ per $\mathrm{m}^{3}$. - Unfortunately, the rainy season is just the period in which fruit or vegetable gardens need no water or little water. The water would therefore have to be stored for use in the dry season. - Now, contrary to popular belief, storage of water is expensive if we use conventional methods. The cost, however, could be brought down very considerably if we were to build extremely large reservoirs and make use of plastic both for the bottoms and for the covers of these reservoirs. - Imagine, for instance a reservoir with a volume of $\mathrm{I}, \mathrm{OoO}, \mathrm{O} 0 \mathrm{~m}^{3}$, built by constructing an earthen dam on a flat plain. Im- 
permeabilisation could be achieved by covering the bottom with a thin plastic film (this was done in 1959 in three large reservoirs near Salt Lake City). The cover could consist of white foam plastic plates floating on the water. - If this kind of reservoir, of the capacity mentioned, could be built for about $f 500,000$ (which will perhaps be possible), it would mean an investment of $f 0.50$ per $\mathrm{m}^{3}$. If the cost of building the reservoir is to be recovered at a rate of $10 \%$ per year, the cost of storage will be $f$ o.o5 per $\mathrm{m}^{3}$. - Taking into account also the cost of delivery from the water-distilling plant to the storage tank, and the distribution to and in the planting area (which, of course, has to be very near to the reservoir), we may have an ultimate cost of irrigation of $f 0.15-f 0.20$ per $\mathrm{m}^{3}$. Naturally all this would have to be investigated in much greater detail. - With a reservoir of $\mathrm{r}, 000,000 \mathrm{~m}^{3}$, between one hundred and two hundred ha of fruit groves and horticultural land could be irrigated!

I I I

Some people think that, given the market demand on Curafao (see 94), there should be a possibility of expanding poultry and egg production considerably. Can this opinion be confirmed?

Any really serious technical and economic study of the matter will reveal that the desired expansion is not so easy as it seems. - It is true that about 4 million eggs are imported yearly, but these are used chiefly in restaurants and bakeries. They are considerably cheaper than the fresh eggs produced on the island: $f$ r.ro per dozen as against about $f$ I.5O per dozen. The same applies to poultry. More than 500 tons per year is imported, as already stated; but this frozen commodity is sold at approximately $f 2$ per $\mathrm{kg}$ as compared with approximately $f 3$ for the fresh article. - We have to take into account several facts which make it difficult for the home product to compete with the imported stuff, one of which is that all the poultry food has also to be imported. - Disregarding tariff barriers, it seems that a considerable expansion of the island's production can only be absorbed by the market if prices are reduced. The profit margin of the producers, however, is low, and it is doubtful whether there are any real possibilities of reducing the cost of production.

\section{Recommendations}

112

Is it possible to give a summing up of the recommendations following from the foregoing discussions?

These recommendations can be formulated as follows:

I. To halt the infiltration of sea water and the deterioriation of the vegetation, which have reached very serious and deplorable proportions in the 'second district', it is necessary to stop ground-water extraction by the Government and Shell Curaçao N.V. as soon as possible (see Nos. 37-44). 
2. A 'water law', should be promulgated on two main principles, to wit: a) whether the water extracted is used for the creation of vegetation (agricultural or ornamental) or not, and $b$ ) whether the party extracting the water does or does not replenish the ground-water reserves to a degree comparable with the extraction. - From these principles it can be deduced that Government and Shell have to stop extraction, but private citizens not. - An elaborate system of checking all private wells is both impracticable and unjustified (see Nos. 45-6o).

3. The cesspools of the private houses in the second district have a considerable effect on the replenishment of ground water - an effect which is, in fact, many times as important as the effect of all the dams in the second district. It is a mistake to install sewage systems, which lead the used water to the sea, in low-cost housing projects. This practice has to be abandoned (see Nos. 51, 53-60).

4. The function of the multitudinous dams formerly found on the island is generally misjudged. They did not materially help to effect a general rise of the ground-water level. In fact, the quantity of water forced into the soil by dams could have represented no more than a small fraction of the total replenishment of the ground water. - The influence of the dams (only functioning in about two rainy seasons out of every six-years rain cycle) was mainly $a$ ) to extend the 'growing season' of non-irrigational crops, and $b$ ) to 'flush' the salt, which accumulated in the 'dry' years, out of the fruit groves and intensively used, irrigated horticultural lots. - From this it follows that the 'old' method of building a very large number of low dams at the particular places where they serve agriculture best is better than the 'new' method of building a few big dams to 'systematically' block all run-off from the catchment areas. - All Government and Shell land has now been dammed by the new method. - In view of the radically changed pattern of residential areas, and the drastic decline of nonirrigational agriculture, in most cases there is little sense in destroying the big dams once they have been built and trying to recreate the old pattern of low dams (see Nos. 5-21, 60-62).

5. There is not much point in the Government's trying to improve the dam system of the private ground by using the same methods as were used by them in the dam-building campaign round about 1950 , and by Shell (the function of the Shell dams is quite different from what the Government should strive for.) - Dams should only be built after an 'agricultural pattern' has been planned for a given piece of land, and they have to be designed so as to fit this pattern. Otherwise they may do more harm than good. - If the Government wants to go in for such 'land-use' planning for private ground as well, it is recommended that efforts be concentrated on horticulture and fructiculture rather than on staplefood production (see Nos. 27-30).

6. Whilst, contrary to popular belief, the 'run-off' from non-paved areas taken as an average for a six-years rain cycle, is very low $(0.5-1 \%$ of the total rainfall), it may be considerable in paved and built-up areas. For this reason it would be worth while, from purely hydrological considerations, to have dams and infiltration basins in these areas. Unfortunately, however, to avert the danger of flooding roads, gardens and 
houses, Public Works has to plan a discharge of the run-off water as quickly as possible into the sea. - If, at long last, a 'zoning law' were to be promulgated on the island, it is recommended that serious study should be given to the possibility of whether infiltration areas could be spared in drawing up the development plans ('bestemmingsplannen') according to this law (see Nos. 21-23).

7. Deforestation for the export of valuable wood (pockwood and logwood), for the preparation of agricultural land and home sites, for charcoal and lime burning, and even for alleged water-conservation purposes has taken a heavy toll of the island's vegetation, bringing in its wake considerable erosion. Contrary to common opinion, the influence of goats on deforestation seems not to have been important. On the other hand, these animals, freely roaming about, may endanger attempts at artificial reforestation, whilst also preventing the (slow) natural recovery of certain kinds of valuable vegetation (especially the spreading of pockwood in areas which are denuded by man). - The Government should buy the tracts of land in the third district which are still densely wooded. - Parklike areas should be created in some easily reforestable tracts of flat land (e.g. Klein Kwartier, northern part of Groot Piscadera). - The possibility of reforestation and erosion control on the many naked or nearly naked hills in the second district should be studied. For several reasons this is a very difficult task, the different aspects of which have been extensively discussed above. 'Ringing' of the hills with low earthen dams or terracing with low stone banks might be part of the answer (see Nos. 63-9o).

8. Attempts at reforestation should be combined with efforts towards appropriate landscaping of the city and the countryside. This is of primary importance for touristic development. - In this connection the first thing to do is to compose a 'Manual of the Use of Indigenous Plants', in which the habits and properties of these plants are carefully described (drought-, wind-, salt- and goat-resistance, shedding of leaves, speed of growth, crown development, flowers, etc.). It is proposed to assign this task primarily to the author of the 'Gekweekte en nuttige planten van de Nederlandse Antillen' and the 'Zakflora. Wat in het wild groeit en bloeit op Curaçao, Aruba en Bonaire'. - Secondly, it is necessary to obtain the services of a professional landscape architect who is well acquainted with drought-resistant tropical and sub-tropical plants. This man should also help with the introduction of new plants which could be used for reforestation and landscaping. - Lastly, the mania for having 'clearing gangs' of relief workers to cut down young trees alongside roads has to be held in check.

9. There seems to be a reasonable chance of considerably developing horticulture and fructiculture. The best way should be to help persons with a thorough practical knowledge in these fields to start large farms on selected sites and according to rationalized methods (see also report: 'Rationalisatie van de tuinbouw'). Development in the other branches of agriculture seems doubtful or impossible (see Nos. 94-1II).

Io. Cheap distilled water is of great importance for the vegetation on the island. If this is available, ground-water extraction for household and 
garden use will automatically diminish greatly, and it will materially help horticulture and landscaping. In close coöperation with Shell Curaçao N.V., the Government should strive to obtain very large distilling equipment, utilizing the most advanced techniques, which will probably be available within five years or so, in order to reduce the cost of water drastically and fundamentally. Possibilities should also be studied of cheap water storage in large basins lined with plastic foil (see Nos. 50-5I, 100, I10).

II. It is recommended that a series of boreholes should be drilled in conjunction with geological investigations, to examine the underground water situation, especially in the limestone areas (see Nos. 24-36 and 92).

\section{REFERENCES}

(arranged chronologically)

Geologie en Geohydrologie van het eiland Curaça, by G. J. H. MolengraAfF. Thesis, Delft, 1929; Part II: 'Geohydrologie', p. 99-126, with 2 plates and 5 loosely inserted folding tables \& maps.

'Radulphus Report':

Rapport en notulen van de Commissie ingesteld ... ter bestudeering van het grondwaterprobleem op Curafao. Rapport van het Hoofd van den Landswatervoorzieningsdienst inzake: de grondwateronttrekking voor de Watervoorzieningsdienst op Curaçao; en het grond-en valleiwater op Aruba ... Curaçao, (April) 1946, iv $+5^{8}$ pp. mimeogr., 17 folding maps.

'Krul Report':

Rapport inzake de waterhuishouding van Curaçao en Aruba, by W. F. J. M. KRUL. Rijksinstituut voor Drinkwatervoorziening, 's-Gravenhage, (July) 1949, (iv) + 43 pp. mimeogr. - With 3 annexes: I, Beschouwingen over de regenval, by W. C. VISSER, i +8 pp., 4 separate drawings. II, Nota inzake de hydrologie van Curaf̧ao en Aruba, by G. SANTING, (v) +85 pp. portfolio of ro maps and tables. III, Nota betreffende de landbouw van Curaf̧ao en Aruba, by W. C. VISser, ii $+5^{6}$ pp., 4 separate drawings and $I$ folding table.

Resultaten van de studie van het rapport van Prof. W. F. J. M. Krul: 'De waterhuishouding van Curaf̧ao en Aruba' ... Meded. Voorlichtingsinstituut voor het Welvaartsplan Nederlandse Antillen, Amsterdam, No. 2, 1950, 26 pp. mimeogr. - With critical comments by J. H. WestermanN.

De waterhuishouding van Curaçao en Aruba, by P. WAGENAAR HUMMELINCK. 'De West-Indische Gids' 3I, 1950, p. 21-42. - Review of the report by Prof. Krul and collaborators on the hydrology and water supply of Curaçao and Aruba; with critical comments.

Het vraagstuk van het behoud van het water op Curaf̧ao, by J. BeIJERING. 'De West-Indische Gids' 3I, I950, p. 65-79, 4 figs. - Summary: on water and soil conservation on Curaçao. 
Grondwaterpeil en watervoorziening op Curafao, voorheen en thans, by N. van Meeteren. 'De West-Indische Gids' 3I, 1950, p. 129-169, I fig. - Sinopsis: El nivel del agua en el subsuelo de Curaçao y su explotación antes y hoy.

Een onderzoek naar de waterhuishoudkundige grondslagen van de landbouw op de Benedenwindse Eilanden, by W. C. VISSER. 'Landbouwkundig Tijdschrift' 63, 1951, p. 293-301.

De waterhuishouding op de Nederlandse Antillen in de laatste tien jaren by G. SANTING. Jaarboek 1948-1951, Uitgaven 'Natuurwetenschappelijke Studiekring voor Suriname en de Nederlanden Antillen' Utrecht, No. 6, I95I, p. 67-74.

Gekweekte en nuttige planten van de Nederlandse Antillen, by Fr. M. ARNOLDO (A. N. Broeders). Uitgaven 'Natuurwetenschappelijke Werkgroep Nederlandse Antillen' Curaçao, No. 3, June 1954, viii + r49 pp., 225 photographs on 63 plates excluded. - Cultivated and useful plants of the Netherlands Antilles.

Wat in het wild groeit en bloeit op Curaçao, Aruba en Bonaire. Zakflora, by Fr. M. ARnoldo (A. N. Broeders). Uitgaven 'Natuurwetenschappelijke Werkgroep Nederlandse Antillen' Curaçao, No. 4, October 1954, viii + I70 pp., I56 photographs on 68 plates excluded. - The Pocket Flora of Curaçao, Aruba and Bonaire.

The Vegetation of the Netherlands Antilles, by A. L. Stoffers. Uitgaven 'Natuurwetenschappelijke Studiekring voor Suriname en de Nederlandse Antillen' Utrecht, No. 15. 1956; Utrecht 1956, iv + 142 pp., 12 figs., 52 photographs on 28 plates, 4 loosely inserted coloured folding maps.

Photo-geological Observations and Land Capability \& Land Use Survey of the Island of Bonaire, by J. H. Westermann \& J. I. S. Zonneveld. Mededeling Koninklijk Instituut voor de Tropen, Amsterdam, No. 123 (Afd. Trop. Prod. No. 47), 1956, roo pp., table on p. Ior-131, 5 figs., 6I photographs on 35 plates excluded. - Dry-farming and its technical possibilities for the Netherlands Antilles, by B. A. BrtreR, p. 75-79.

Rationalisatie van de tuinbouw, by P. C. HenRIQUez. Report appended to 'Deel I, Tienjarenplan van de Centrale Regering der Nederlandse Antillen', July 1962.

Acknowledgements: The author is much indebted to Brother M. ARNOLDO, for much useful information on botanical problems, and to Dr. P. WAgenaAR Hummelinck, for his critical scrutiny, comments and suggestions in editing this publication. 


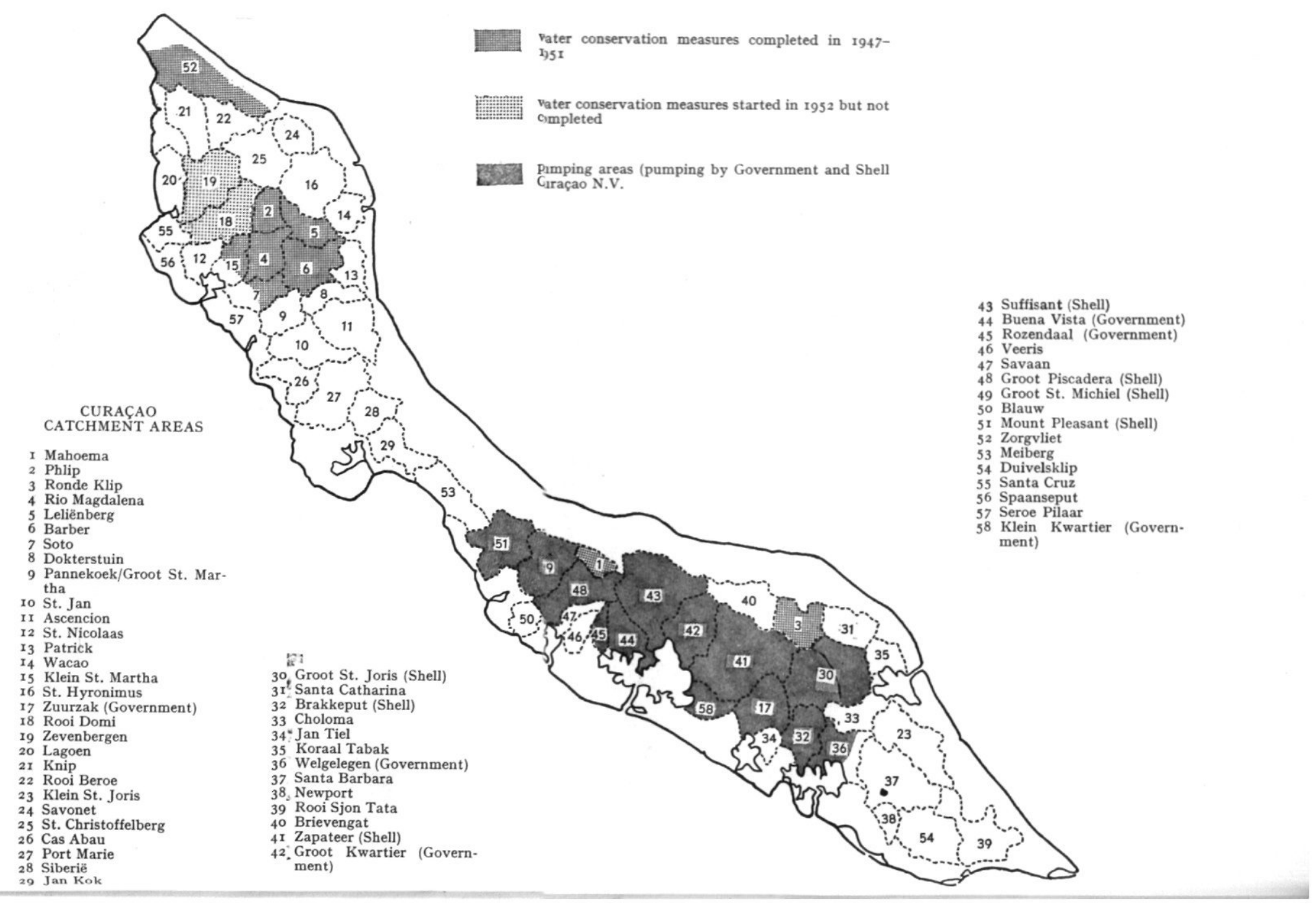




\section{INDEX}

Nos. of questions and answers

Agriculture, areas cleared for . . . . . . . . . . 93

-, dry-farming methods . . . . . . . . . . . . 96

一, formerly and now . . . . . . . . . . . . . 93-94

—, former importance . . . . . . . . . . . . . . . 93

—, in Negev desert . . . . . . . . . . . . . . 98

—, organisation needed for improvement. . . . . 97

-, possibilities of restoring . . . . . . . . . . . 94-109

Cacti, caterpillar eating . . . . . . . . . . . 84

Caliche . . . . . . . . . . . . . . . . . . 4

Capacity of subsoil to hold water . . . . . . . . 3

Cesspools, compared with dams . . . . . . . . . 60

-, replenishment of ground water by . . . . . 51-60

Chicken farming, see: poultry

City planning, water conservation and . . . . . 23

Climate, alleged change of . . . . . . . . . 63

Complexity of subsoil . . . . . . . . . . . 4

Dairy farming . . . . . . . . . . . . . . 93-94

Dams, areas completely provided with . . . . . . 27

—, areas not completely provided with . . . . . 27

—, big. . . . . . . . . . . . . . . . . . . . 9, 16-17

—, compared with cesspools . . . . . . . . . . 60

—, former number of . . . . . . . . . . . . . 7

—, function in fruit groves. . . . . . . . . . $\mathbf{1}_{4} \mathbf{- 1 5}$

-, function of . . . . . . . . . . . . . . . . 8

-, influence on water table . . . . . . . . . $16,18-21,62$

—, on private estates . . . . . . . . . . . . . 27-30

-, penetration of water in front of . . . . . . . 9-14

—, quantity of water caught by . . . . . . . 19, 21, 42, 60-6I

—, small versus big . . . . . . . . . . . . . . 17

-, use in agriculture and horticulture . . . . . . 8

Deforestation, and water extraction . . . . . . 90

-, through water extraction . . . . . . . . . . 39-45

-, causes of . . . . . . . . . . . . . . 64 


\section{Nos. of questions \\ and answers}

-, for alleged water conservation . . . . . . . . 82, 90

-, see 'Krul Report' and 'Radulphus Report'

-, still practised . . . . . . . . . . . . . . . 9 I

-, versus reforestation . . . . . . . . . . . . 86-90

Denudation, see: deforestation

Diabase, structure .. . . . . . . . . . . . 3

-, water-holding capacity . . . . . . . . . . 3,4

Distilled water . . . . . . . . . . . . . . . . 50-5I

-, cheap for horticulture and fructiculture . . . . I Io

- cheap reservoirs for ............. IIo

Dry farming . . . . . . . . . . . . . . . . . 96

Egg production, possibilities of improvement . . . 94, 1 I I

Erosion . . . . . . . . . . . . . . . . 31-32

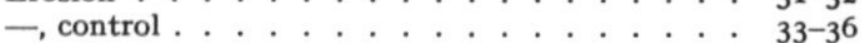

'Fahas' . . . . . . . . . . . . . . . 33-35

Forest, primary and secondary . . . . . . . . . 65

-, vegetation in secondary . . . . . . . . . . . 65

Fructiculture, possibilities for improvements . . . 94, 104, 109

一, yield per ha . . . . . . . . . . . . . . . . 109

Fruit groves, death of . . . . . . . . . . 39-4I, 43

-, list of . . . . . . . . . . . . . . . . . . 94

Fruits, see: fructiculture

Goats, and primary forest . . . . . . . . . 66

-, and secondary growth . . . . . . . . . . 67,71

-, control of grazing . . . . . . . . . . . . 72-73

-, destroying pockwood . . . . . . . . . . . . 69

—, fencing-off of ground against . . . . . . . . 75

-, intensivation of keeping . . . . . . . . . . 74

-, plants not eaten by . . . . . . . . . . . . 83

Government, building of dams on private estates by $27-30$

Grazing, see: goats

Ground water, see: water

Guayaca, see: pockwood

Hills, reforestation .. . . . . . . . . $36,77-78$

Horticulture, possibilities for improvement . . . . 94, 100, 104

Hydrology . . . . . . . . . . . . . . . . $1-30$

一, and drilling . . . . . . . . . . . . . . . 92

-, differences between Neth. Antillean islands . . I

-, difference from other semi-arid regions . . . . 2, 3

Infiltration of sea water (see also: water extraction) $39-40$

Infiltration of water through cesspools . . . . . 51-6o

-, of water in dam basins . . . . . . . . . . . 9-13

'Krul Report' . . . . . . . . . . . . . . 44, 86-90 
Nos. of questions and answers

Landscaping, see: reforestation . . . . . . . .

Lignum vitae, see: pockwood

Limestone areas, hydrological condition of . . . . 24-26

Opuntias, destruction of . . . . . . . . . . . . $8_{4}$

Overpumping, see: water extraction

Paved areas, run-off in . . . . . . . . . . 21

一, water conservation in . . . . . . . . . . . 23

Penetration of water in dam basins . . . . . . . 9-13

-, of water in residential areas . . . . . . . . . 23

Plants, see: deforestation, reforestation, goats, water extraction

Pockwood . . . . . . . . . . . . . . . . . . 63

Poultry production, possibilities for improvements 94, I I I

Private estates, building of dams by government on 27-30

'Radulphus Report' . . . . . . . . . . . . . . 4I, 44

Rain, fate of - falling on the island . . . . . . . 6

Recommendations, summary of . . . . . . . . . 112

Reforestation .. . . . . . . . . . . . . $76-88$

—, adverse influence on water conservation . . . 88, 89

—, and water table . . . . . . . . . . . . . . 90

—, areas to be reforested . . . . . . . . . . . 8I

—, combined with erosion control . . . . . . . . 77

—, difficulties . . . . . . . . . . . . . . . . 76

-, good influence on water conservation. . . . . 87

-, introduction of new plants for . . . . . . . . 85

一, of hills . . . . . . . . . . . . . . . . $77-78$

-, of valleys . . . . . . . . . . . . . . . . . 82

—, requirements for trees used in . . . . . . . . . 79

-, trees for . . . . . . . . . . . . . . . . 82

-, use of cacti and agaves ... . . . . . . . . . . 80

—, use of goat-resistant plants . . . . . . . . . 83

-, versus deforestation . . . . . . . . . . . . 86-90

Residential areas, water conservation in . . . . . 23

'Ringing' of hills . . . . . . . . . . . . . . . 36, 77

Roads, see: paved areas

一, trees along . . . . . . . . . . . . . . . . 9I

Run-off . . . . . . . . . . . . . . . . . . . $6,18,21$

-, from paved areas . . . . . . . . . . . 22

Sea-water distillation . . . . . . . . . . . . 50-51

Sea water, infiltration of (see also: water ex-

traction) . . . . . . . . . . . . . . . 39-40

Sedimentary material . . . . . . . . . . . . . 3

Sewage system versus cesspools . . . . . . . . 54-60

Silt, deposited in dam basins . . . . . . . . . 9-13, 32

Sorghum, see: staple food 
Nos. of questions

and answers

Staple food, production formerly . . . . . . . . 93

-, production, possibilities for improvement . . . 9I, 95-98

Stock, for meat, production formerly . . . . . . 93-94

Stone banks . . . . . . . . . . . . . . . . . 33-35

Subsoil, capacity to hold water . . . . . . . 3, 6, 9, 24

一, complicated structure . . . . . . . . . . . 4

'Terracing' . . . . . . . . . . . . . . . . . 34-35

Trees, see: deforestation, goats, reforestation, water extraction

Trenches for reforestation . . . . . . . . . . . 77

—, on hillsides . . . . . . . . . . . . . . . . 36,77

Tuffs . . . . . . . . . . . . . . . . . . 4

Vegetables, see: horticulture . . . . . . . . . .

Vegetation, see: deforestation, reforestation, water extraction, forest

一, original................ . . 64, 66

Water, penetration of . . . . . . . . . 9-13

-, replenishment of ground water by cesspools . . 51-60

Water conservation, see: dams, run-off, penetration,

erosion control, reforestation, deforestation, water law, water extraction

一, in residential areas ............ 23

Water extraction . . . . . . . . . . . . $37-45$

一, and deforestation . . . . . . . . . . . . . 90

—, by Government and Shell . . . . . . . . . $21,41-42,46-47,53$

一, death of trees through . . . . . . . . . . . . 39-45

一, stopping of . . . . . . . . . . . . . . . 47, 50

Water distillation . . . . . . . . . . . . . . $50-5 \mathbf{I}$

Water-holding capacity, limestone . . . . . . . 24

一, subsoil . . . . . . . . . . . . . . . . . . 3, 24

Water law . . . . . . . . . . . . . . . $44^{8-49,52}$

Water management, see: water law

Water table, lowering of (see also: water extraction) $\quad 37-45$

Wells, erratic behaviour of . . . . . . . . 4

—, in limestone areas . . . . . . . . . . . . . . 24

一, salting-up . . . . . . . . . . . . . . . . . 39-40

Wood, export of ............. . . . 64

Zoning.................. . . 9 